\title{
ПРИРАЗЛОМНЫЕ ТЕКТОНИТЫ ЕНИСЕЙСКОГО КРЯЖА. СТАТЬЯ 1: ГЕОЛОГО-СТРУКТУРНЫЕ, МИНЕРАЛОГИЧЕСКИЕ И ГЕОХРОНОЛОГИЧЕСКИЕ СВИДЕТЕЛЬСТВА ПОЛИМЕТАМОРФИЗМА
}

\author{
И. И. Лиханов ${ }^{1}$, А. А. Крылов ${ }^{1}$, Ж.-Л. Ренье ${ }^{2}$ \\ ${ }^{1}$ Институт геологии и минералогии им. В. С. Соболева СО РАН, Новосибирск, \\ ${ }^{2}$ Университет Мугла, Мугла, Турция
}

Поступила в редакцию 28 марта 2018 г.

\begin{abstract}
Аннотация: в пределах Приенисейской региональной сдвиговой зоны Енисейского кряжа изучень метапелиты и метабазиты, подвергшиеся интенсивным деформациям с перекристаллизаџией субстрата и образованием тектонитов. Наложение более поздних минеральньх ассоичаций на ранние в ходе разных геодинамических событий четко фиксируется по геолого-структурным особенностям доменов сильно- и слабодеформированных пород, реакиионным микротекстурам, химической зональности минералов и изотопным датировкам. Такие индикаторные признаки свидетельствуют о полиметаморфической истории пород, контролируемой разньми тектоническими обстановками. Неоднородность метаморфических преобразований и особенности реологии пород указывают на возможность генерации сверхдавлений и роста температуры в шовньх зонах земной коры, что требует подтверждения надежными геотермобарометрическими расчетами. В связи с этим, полученные данные являются базисом для последующей реконструкиии тектоно-термальной эволючии региона и ее интерпретации в рамках популярных тектонических моделей.
\end{abstract}

Ключевые слова: тектониты высокого давления, петрография, микротекстуры, химия минералов, деформация, Енисейский кряж

\section{FAULT TECTONITES OF THE YENISEI RIDGE: 1: GEOLOGICAL, TEXTURAL, MINERALOGICAL, AND GEOCHRONOLOGICAL EVIDENCES FOR POLYMETAMORPHISM}

\begin{abstract}
Metapelites and metabasites subjected to intensive deformations with recrystallization of the substrate and the formation of tectonites have been studied within the Yenisei regional shear zone of the Yenisei Ridge. Overprinting of the later mineral assemblages on the early during subsequent tectonic events as a result of different geodynamic processes is clearly recorded by the geological and structural features of rheology of deforming rocks, reaction microtextures, chemical zoning in minerals, and isotopic dating. These indicators provide evidence for the polymetamorphic history of rocks and suggest distinct tectonic processes. Such rock behavior between superimposed metamorphic events could be generated with intense shear deformation in an inhomogeneous environment, suggesting a tectonic control over the late stage of metamorphism in the suture zones of the earth's crust and possibility for the existence of tectonic overpressure. In order for the present suggestions to be considered more reasonably, further robust geothermobarometric evidence is required in support of overpressure, including P-T estimates for intensely deformed tectonites compared to the background values of the earlier metamorphic events, measured from the less deformed rocks. The obtained data are the basis for the subsequent reconstruction of the tectono-thermal evolution of the region and its interpretation within the framework of known tectonic models.
\end{abstract}

Key words: high-pressure tectonites, petrography, microtextures, mineral chemistry, deformation, Yenisei Ridge 


\section{Введение}

Статья направлена на решение одной из актуальных геологических проблем - соотношения деформационных и метаморфических процессов в земной коре и их генетической взаимосвязи. Перспективными объектами для выяснения этих вопросов являются глубинные зоны пластических сдвиговых деформаций. Интерес к этим зонам обусловлен фундаментальными (исследование процессов стрессметаморфизма) и прикладными (связь с этими процессами очагов землетрясений) аспектами.

В научной литературе последних лет особое внимание уделяется окраинно-континентальным сдвиговым зонам - областям объемного хрупко- и вязкопластического течения горных масс, локализованным вдоль узких линейных структур земной коры. Эти зоны являются обязательным элементом структуры орогенных поясов [1-3]. Они встречаются в различных геодинамических обстановках и, как правило, контролируются комплексами орогенных и рифтогенных бластомилонитов [4], значение которых для тектонических реконструкций раньше сильно недооценивалось. Дефицит данных о термодинамических параметрах и времени проявления синсдвиговых деформаций в глубинных зонах земной коры привел к господствующим в литературе представлениям о второстепенном вкладе деформационной компоненты в общую энергетику формирования региональных метаморфических структур [5].

Однако в последнее время выявлена важная роль синсдвиговых метаморфических процессов в формировании структур складчатых поясов, что обусловило приоритетное использование продуктов динамометаморфизма для решения многих петрогенетических проблем. В частности, были детально изучены процессы фрагментации вещества с обособлением реологически контрастных доменов с индивидуальной $P-T$ $t-d$ историей формирования $[6,7]$, выявлены соотношения литостатического и тектонического давления в глубинных зонах пластических сдвиговых деформаций [8-11]. Особенно активно в современной литературе обсуждается роль тектонического стресса как дополнительного фактора метаморфизма в связи с вопросами генерации сверхдавлений в субдукционных и сдвиговых зонах [12]. Прогресс в этом направлении позволил на основе модельных примеров создать современную теоретическую концепцию тектонического давления, определяющую природу сверхдавления и вариаций давления в связи с деформациями пород и их реологическими свойствами [13]. Эти представления были подтверждены результатами численного моделирования баланса сил в развивающемся сдвиговом нарушении [14-18]. Результаты показали, что тектоническое сверхдавление в породах может быть значительно выше, чем девиаторный стресс, отражающий литостатическую нагрузку, что указывает на существование гетерогенного стресса и значительных отклонений давления от литостатического в земной коре.
Тем не менее, несмотря на возрастающий интерес к этой проблеме, природные наблюдения этого явления пока ещё достаточно редки. В этой связи можно упомянуть всего лишь несколько работ [19-27]. В настоящей статье на примере приразломных тектонитов контрастного химического состава Приенисейской региональной сдвиговой зоны (ПРСЗ) приведены геологоструктурные, минералогические и геохронологические свидетельства полиметаморфической эволюции пород, контролируемой разными тектоническими механизмами. Выявленные эмпирические данные являются базисом для последующей реконструкции тектоно-термальной эволюции региона и ее интерпретации в рамках известных тектонических моделей, которые будут рассмотрены в следующей авторской статье.

\section{Геологические особенности и основные}

\section{структурные элементы Енисейского кряжа}

Енисейский кряж расположен на западной окраине Сибирского кратона, протягиваясь в субмеридианальном направлении вдоль р. Енисей почти на 700 км при ширине от 50 до 200 км (рис. 1б). Геофизические данные свидетельствуют о вертикальном утолщении и транспрессионной обстановке: ширина складчатой области Енисейского кряжа на глубине более 10 км вдвое уменьшается, что придает ему грибовидную форму [28]. Глубина залегания поверхности Мохоровичича под Енисейским кряжем по сравнению с соседними регионами увеличена от 40 до 50 км [29]. Таким образом, этот складчатый ороген обладает структурой с утолщенной корой, сохранившейся в течение длительного геологического времени. Коллизионная модель формирования структуры земной коры в регионе подтверждается данными сейсмического профилирования и обосновывается «скучиванием» пород неопротерозойских формаций [30]. В строении Енисейского кряжа выделяются два крупных сегмента - Южно-Енисейский и Заангарский, разделенные субширотным Нижнеангарским региональным разломом [31]. На юг от этого разлома выделяется два структурных элемента - архей-палеопротерозойский кратонный Ангаро-Канский блок, образованный канским гранулито-гнейсовым и енисейским гнейсовосланцевым комплексами и гранитоидами, и неопротерозойский островодужный Предивинский террейн [32] (рис. 1a). К северу от Нижнеангарского разлома, в заангарской части, Енисейский кряж сложен палеопротерозойскими и мезо-неопротерозойскими породами, составляющими Восточный (приплатформенный) и Центральный кратонные блоки, и Исаковский (западный) террейн, представленный неопротерозойскими офиолитами и островодужными комплексами [33] (рис. 2a). Палеоокеанические террейны аккретировали к Сибирскому континенту в венде ( 600 млн лет), маркируя время завершающего этапа неопротерозойской эволюции Енисейского кряжа [34].

Объекты исследования расположены в южной и северной части Енисейского кряжа в пределах ПРСЗ, 


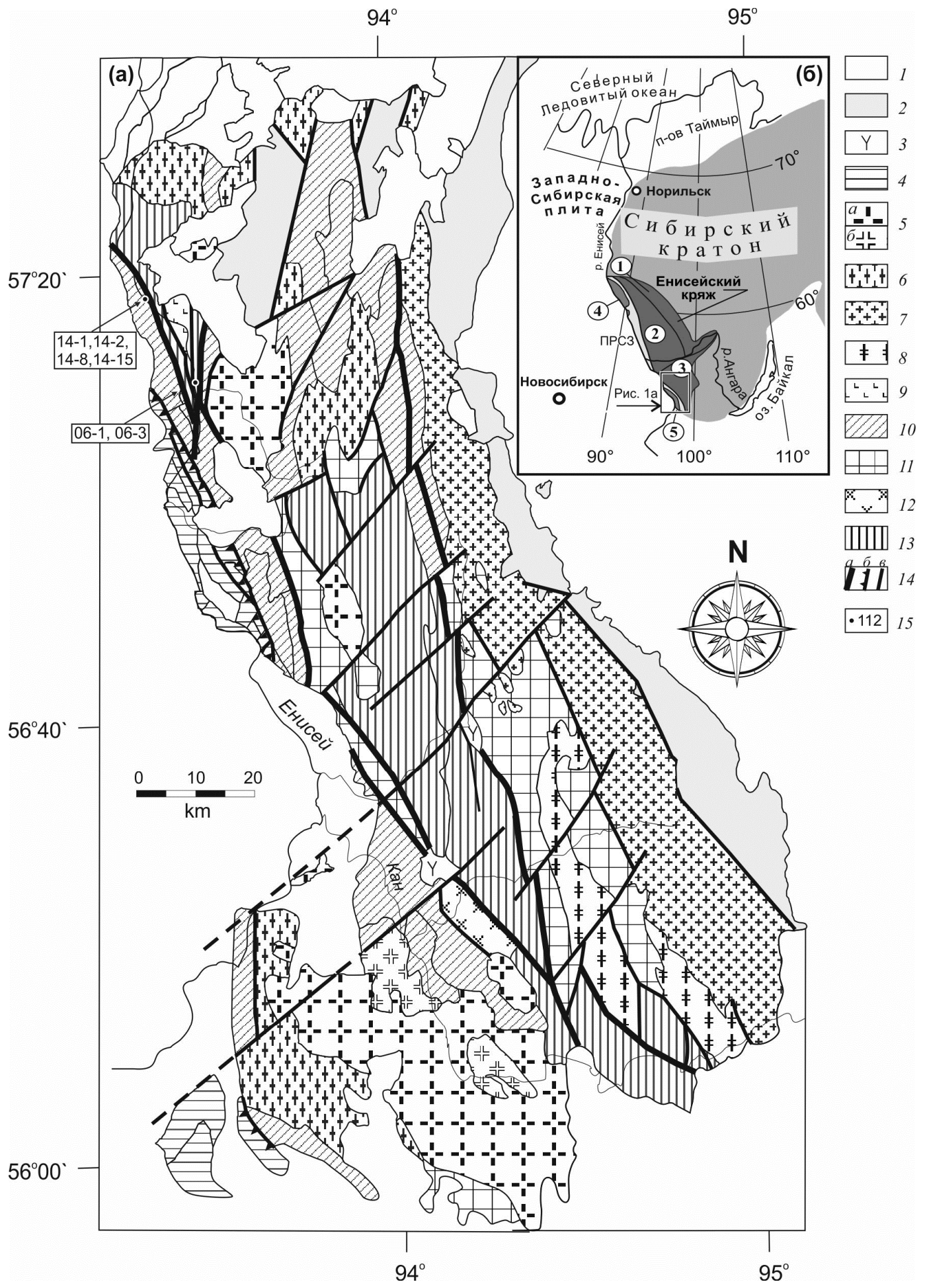

Puc. 1. (а) Схема геологического строения Ангаро-Канского выступа Енисейского кряжа и местоположение объектов исследования. (б) - положение ПРСЗ (светло-серый оттенок) и тектонических блоков на западной окраине Сибирского кратона (б): $I$ - Восточный (приплатформенный) и II - Центральный Заангарского сегмента; III - Южно-Енисейский (Ангаро-Канский) сегмент, $I V-$ Исаковский и $V$ - Предивинский островодужные блоки. 1,2 - отложения фанерозойского (1) и позднепротерозойского (2) возраста; 3 - порожненский комплекс сиенитов и щелочных гранитов (V?); 4 - юксеевский комплекс островодужноофиолитовых образований (R?); 5 - комплекс аллохтонных гранитоидов (граниты (а), диориты (б) $\left(\mathrm{PR}_{2}\right.$ ?); 6 - комплекс реоморфическиз гранитов $\left(\mathrm{PR}_{2}\right.$ ?); 7 - таракский гнейсогранитный комплекс $\left(\mathrm{PR}_{1}\right) ; 8$ - мигматит-гнейсовый комплекс $\left(\mathrm{PR}_{1}\right) ; 9$ - кимбирский комплекс расслоенных габброноритов $\left(\mathrm{PR}_{1}\right.$ ?); 10 - енисейский амфиболит-гнейсовый комплекс $\left(\mathrm{PR}_{1}\right)$ : двуслюдяные гнейсы с прослоями амфиболитов и метакарбонатных пород (а); кордиеритовые гнейсы (б); 11 - атамановский гранулит-гнейсовый комплекс (AR?); 12 - чарнокит-гнейсовый комплекс (AR?); 13 - кузеевский гранулит-метабазит-гнейсовый комплекс (AR?); 14 - тектонические нарушения: протяженные зоны разломов с бластомилонитами и катаклазитами (а), надвиги (б) и основные разломы (в); 15 точки отбора образцов. 


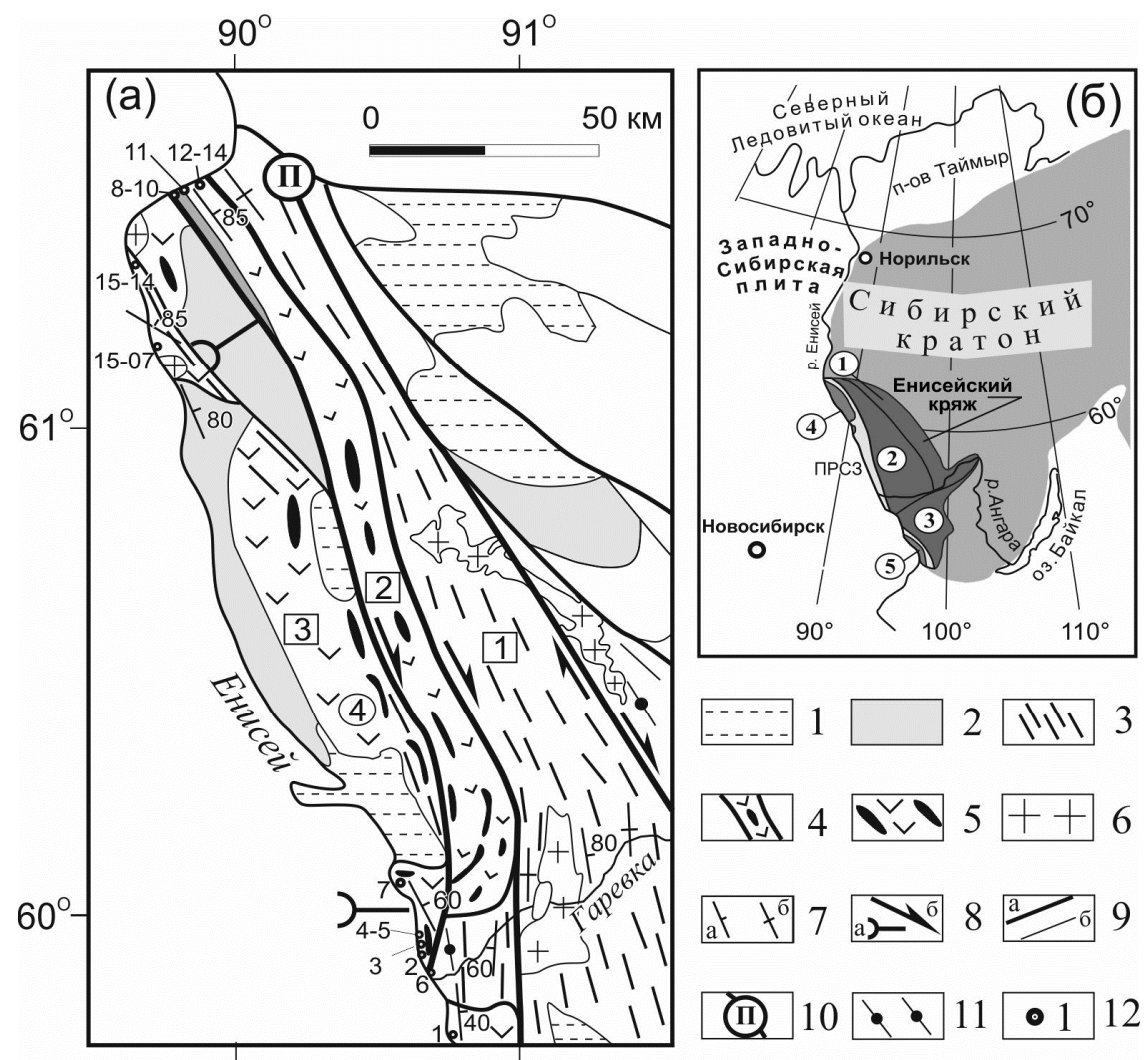

Puc. 2. (а) Схема геологического строения северной части Заангарья Енисейского кряжа; (б) - положение ПРСЗ (светлосерый оттенок) и тектонических блоков на западной окраине Сибирского кратона: 1 - чехол (Pz-Kz); 2 - молассы (NP2-3); 3 бластомилониты (NP) по породам гаревского комплекса (PР) (зона 1); 4 - высокобарические метабазит-ультрабазитовые и апогнейсовые бластомилониты (зона 2); 5 - метабазитовые и молассовые комплексы Исаковского террейна (зона 3); 6 - гранитоидные комплексы; 7 - элементы залегания сланцеватости: наклонные (а) и вертикальные (б); 8 - направление тектонических движений (NP): поддвиги (а) и сдвиги (б); 9 - тектонические нарушения: разломы (а), надвиги (б) и прочие границы (в); 10 - Приенисейский разлом; 11 - ставролит-гранат-кианитовые тектониты; 12 - точки отбора образцов (крупным шрифтом показаны точки с находками глаукофана).

являющейся продолжением Байкало-Енисейского разлома (рис. 1б). Эта крупнейшая деформационнометаморфическая линеаментная структура региона разделяет кратонные блоки с островодужными террейнами. Она хорошо прослеживается вдоль Енисейского кряжа и в Туруханско-Норильской тектонической зоне по исчезновению нескольких сейсмических поверхностей и уходит на большую глубину с падением плоскости сместителя на восток [35]. В пределах Енисейского кряжа ПРСЗ отчетливо выделяется по гравитационным ступеням, фиксирующимся на сейсмических профилях. Она представляет собой систему сближенных субпараллельных разломов сдвиговой, взбросовой и надвиговой кинематики, концентрирующих деформации сдвига, а также их комбинаций с проявлениями приразломного катаклаза, меланжирования и динамометаморфизма породных массивов. Её протяженность определяется сотнями километров при ширине зон стресс-метаморфизма до первых десятков километров. Эти зоны играют роль швов, разделяющих тектонические блоки региона, и являются областями их активного взаимодействия. В приразломных зонах по этим породам развиты бластомилониты [36]. Значительная часть этих пород входит в состав суб- дукционно-аккреционного комплекса, где они встречаются в виде тектонических пластин, линз или блоков разной размерности и состава в серпентинитовом меланже. Для них характерны следующие кинематические индикаторы сдвига или перемещения в ходе деформационных событий, которые широко проявлены как на мезо- (породном), так и на микроуровнях [37]: линейная деформационная гнейсовидность, наличие упорядоченных структур пластического течения, растяжение и разрыв складок течения с кулисообразной морфологией, полоски излома в слюдах, «тени давления» перекристаллизованного кварца, Sобразные и сильно деформированные зерна граната со структурами «снежного кома», разрывы минеральных зерен со смещением и формированием «лоскутных» полосок, развитие деформационных двойников и ламелей в плагиоклазах, параллельное распределение мелкозернистых линзообразных минеральных агрегатов, а также рассланцевание, катаклаз и будинаж. В целом, сдвиговые зоны проявлены структурами преимущественно правосдвиговой и подчинённой левосдвиговой кинематики и бластомилонитами с преобладающими элементами ламинарного течения. Границы между породными комплексами маркируются 
поверхностями срыва и притирания.

Часто региональные разломы (Приенисейский, Татарско-Ишимбинский и др.) сопровождаются оперяющими структурами более высокого порядка, вблизи которых формируются надвиги [38]. Это вызывает неоднородный по давлению региональный метаморфизм, выраженный в сочетании фациальных серий низких и умеренных давлений [39-42]. Детальный обзор геохронологии, тектонической позиции и геодинамической природы комплексов, участвующих в строении региона, приведен в работах [43]. Там же представлена хронологическая последовательность крупных этапов и событий в геологической истории Енисейского кряжа, сформировавших его тектонический облик.

В целом, пояс приразломных тектонитов образует секущую относительно генеральных структур северозападного простирания шовную зону мощностью около 15-20 км между континентальным и вулканоплутоническим блоками (рис. 2а). Контакты пояса тектонитов с вмещающими блоками проходят по морфологически выраженным разломам. Интерпретация геохронологических данных разновозрастных популяций монацитов в тектонитах, испытавших перекристаллизацию в ходе последовательных деформационных процессов, указывает на неоднократную активизацию ПРСЗ в регионе в диапазоне времени 1,54-0,6 млрд лет [25]. Об этом же свидетельствует тектонический меланж разновозрастных и разномасштабных блоков высоко- и слабометаморфизованных пород разного состава в серпентинитовом матриксе. Формирование наиболее интенсивно деформированных тектонитов связывается с завершением аккреции Исаковского террейна к западной окраине Сибирского кратона на рубеже около 630-600 млн лет назад [44].

\section{Геолого-структурная и минералого-петрографи- ческая характеристика объектов исследования}

Ангаро-Канский блок. В качестве первого объекта исследования выбраны палеопротерозойские $(1,9-1,75$ млрд. лет) метаморфические породы ЮжноЕнисейского кряжа, распложенные в зоне сочленения канской и енисейской серий (рис. 1) [31]. В районе исследования в составе канской толщи (т.н. 06) в основном развиты Sil-Opx-Grt-Bt-Pl гнейсы. В составе енисейского комплекса (т.н. 14) наибольшим распространением пользуются глиноземистые метапелиты, представленные $\mathrm{Sil}+\mathrm{Grt}+\mathrm{Bt}+\mathrm{Pl}$ гнейсами и кристаллическими сланцами. Символы минералов приняты по [45]. Вязкие сдвиги в приразломных полях сопровождались формированием мощных зон деформаций субмеридианального простирания, отличающихся значительной неоднородностью проявления деформаций, сложным чередованием разномасштабных интенсивно деформированных и недеформированных участков. Это выражается в структурно-текстурных особенностях пород с характерной полосчатой текстурой и одновременным присутствием реликтовых текстур исходных пород и развитых по ним бластомилонитам (рис. 3). Полосчатость в бластомилонитах (ribbon structure) связана с дифференциацией однородного субстрата на обогащенные и обедненные кварц-полевошпатовыми и слюдистыми агрегатами «слои» в условиях регионального сдвига. Такое перераспределение материала происходило одновременно с перекристаллизацией породообразующих фаз и ориентированным упорядочиванием [46].

Основными породообразующими минералами бластомилонитов являются гранат, биотит, силлиманит, кварц и плагиоклаз; непрозрачные минералы представлены ильменитом и рутилом. Изометричные и линзовидные порфиробласты граната часто трещиноваты и содержат мелкие включения кварца, плагиоклаза, биотита, циркона, монацита. Среди гранатов отчетливо выделяются крупная (3-5 мм) и мелкая (до 1 мм) генерации (рис. $3 a-ж$ ). В крупном гранате иногда наблюдаются микротрещины отрыва, характерные для сдвиговых деформаций. Трещинки в гранате выполнены часто биотитом и кварцем (рис. 33). Мелкий синтектонический гранат более поздней генерации обрастает крупные порфиробласты граната ранней генерации, образует скопления в «тенях» давления или самостоятельные сегрегационные обособления линзовидно-полосчатой морфологии, ориентированные вдоль плоскостей скольжения в бластомилонитах (рис. 38,2, ж). Зерна биотита также различаются по размерам и оттенкам плеохроизма в бурых (крупночешуйчатый) и оранжевых (тонкочешуйчатый) тонах. Призматические порфиробласты силлиманита обособляются в существенно биотитовых полосах в парагенезисе с гранатом. Они часто пластически деформированы с характерным изгибом пластинок роста (kink-bands) (рис. 3д) Для кварца характерно волнистое угасание и развитие пластинок деформации (deformation lamellae); в большинстве случаев он формирует линзовидные сегрегационные обособления так называемого «ленточного» кварца (рис. $3 e, 3$ ). Зерна плагиоклаза изгибаются в процессе сдвигового течения материала с характерным вращением зерен (рис. 3e). Монацит присутствует в виде включений как в зернах крупного граната, так и в тонких прослоях раздробленного и интенсивно перетертого матрикса, где по периферии замещается апатитом.

Заангарье. Другой объект работ расположен на северо-западе Заангарья Енисейского кряжа (рис. 2a). В этом районе в строении ПРСЗ выделено 3 крупных блока (с востока на запад): континентальный гнейсоамфиболитовый, метабазит-ультрабазитовый и вулканоплутонический. Континентальный блок сложен породами гаревского метаморфического комплекса, в составе которого наиболее распространены биотитовые плагиогнейсограниты немтихинской толщи и порфиробластические гранитогнейсы и гранатдвуслюдяные кристаллические сланцы малогаревской толщи палеопротерозоя [47]. Последние два блока относятся к Исаковскому террейну. Офиолитовые ассоциации второго блока состоят из меланжированных пластин и линз амфиболизированных толеитовых метабазальтов и метабазит-ультрабазитов (антигоритовых 

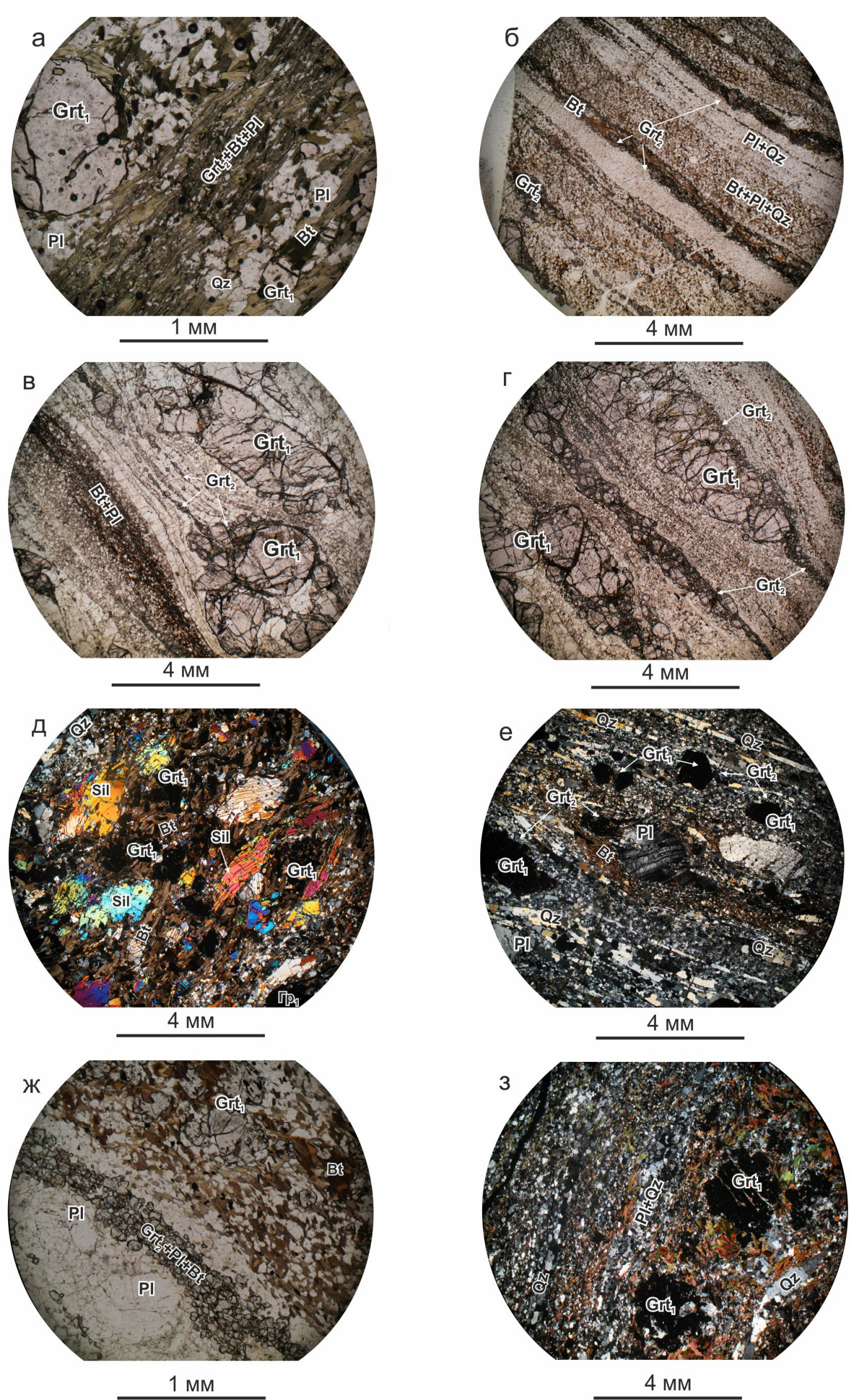

Puc. 3. Свидетельства процессов фрагментации в системе “гнейсы - бластомилониты” и структурно-текстурные особенности бластомилонитов из южного сегмента ПРСЗ Ангаро-Канского блока. $\mathrm{Grt}_{1}$ u $\mathrm{Grt}_{2}$ - гранаты из реликтовых гнейсов и бластомилонитов, соответственно. 
метадунитов и метагарцбургитов с подчинённым количеством антигоритизированных пироксенитов), относимых к фирсовской толще раннего рифея и к сурнихинскому комплексу нижнего-среднего рифея. Вулканоплутонический блок сложен породами метадацитандезит-базальтовой ассоциации, метаморфизованными в условиях фации зелёных сланцев, относящихся к киселихинской толще верхнего рифея [48]. В пределах северного сегмента ПРСЗ изучены образцы метапелитовых и метабазитовых тектонитов шовной зоны из правобережья р. Енисей - участков Осиновских порогов, рек В. Сурнихи, Проклятой и Борисихи, различающихся как по характеру и интенсивности деформаций, так и неоднородностью их вещественного сложения. В самой северной части пояса, в районе Осиновских порогов, в составе меланжа характерны будинированные реликтовые крутопадающие $\left(85-90^{\circ}\right)$ блоки и пластины метапелитовых гнейсов немтихинской толщи палеопротерозоя $\mathrm{Grt}+\mathrm{Bt}+\mathrm{Ms}+\mathrm{Pl}+\mathrm{Qz} \pm \mathrm{Kfs} \pm \mathrm{Chl}$ состава, и будины апобазитовых амфиболитов Grt+Aмp+Pl+Ep+ $\mathrm{Chl}+\mathrm{Ph}+\mathrm{Spn}+\mathrm{Rt}$ состава. В районе p. В. Сурниха и выше её устья в правом борту р. Енисей картируется меланжевая линзовидно-пластинчатая структура, характеризующаяся чередованием тел бластомилонитов и гранатовых амфиболитов с ассоциацией Grt+Aмp+Pl+ $\mathrm{Ph}+\mathrm{Pg}+\mathrm{Ep}+\mathrm{Spn}+\mathrm{Cb}+\mathrm{Chl}+\mathrm{Rt}$ с пластинами будинированных интенсивно серпентинизированных дунитов, реже гарцбургитов и пироксенитов. Породы Борисихинского участка представлены полосчатыми амфибо- литами с крупнокристаллическими линзами-реликтами Pl-Amp состава габброидного облика с возрастом около 680 млн лет [49]. В тонкокристаллических апобазитовых амфиболитах локально развиты изометричные и деформированные зональные гранаты, образующие локальные тонкие (не более 1-3см) полоски и линзы в ассоциации с Амp+Ab+Chl+Ep+Spn агрегатом.

Эти породы входят в состав субдукционноаккреционного комплекса, где встречаются в виде тектонических пластин, линз или блоков в серпентинитовом меланже. Типичной минеральной ассоциацией базитовых тектонитов является $\mathrm{Grt}+\mathrm{Amp}+\mathrm{Pl}+\mathrm{Ep}+$ $\mathrm{Chl}+\mathrm{Ph}+\mathrm{Qz}+\mathrm{Spn}+\mathrm{Rt}+\mathrm{Ilm} \pm \mathrm{Cb}$. По микротекстурным и соотношениям между минералами метабазитов выделяется две стадии развития [50]. Кульминационная ассоциация представлена интенсивно деформированными минералами бластомилонитов (рис. 4). Зерна граната и титанита часто содержат реликтовые включения глаукофана, альбита, фенгита, эпидота и хлорита, что свидетельствует об участии последних в ранней допиковой ассоциации [51] (рис. $4 c, d$ ). Обнаружение реликтовых минералов глаукофансланцевой ассоциации в тектонитах Приенисейской сутурной зоны свидетельствует о проявлении на западе Сибирского кратона конвергентной границы «кордильерского типа», контролируемой субдукцией океанической коры под континентальную окраину [52]. Детальный обзор петрогеохимии изученных комплексов представлен в работе [51].
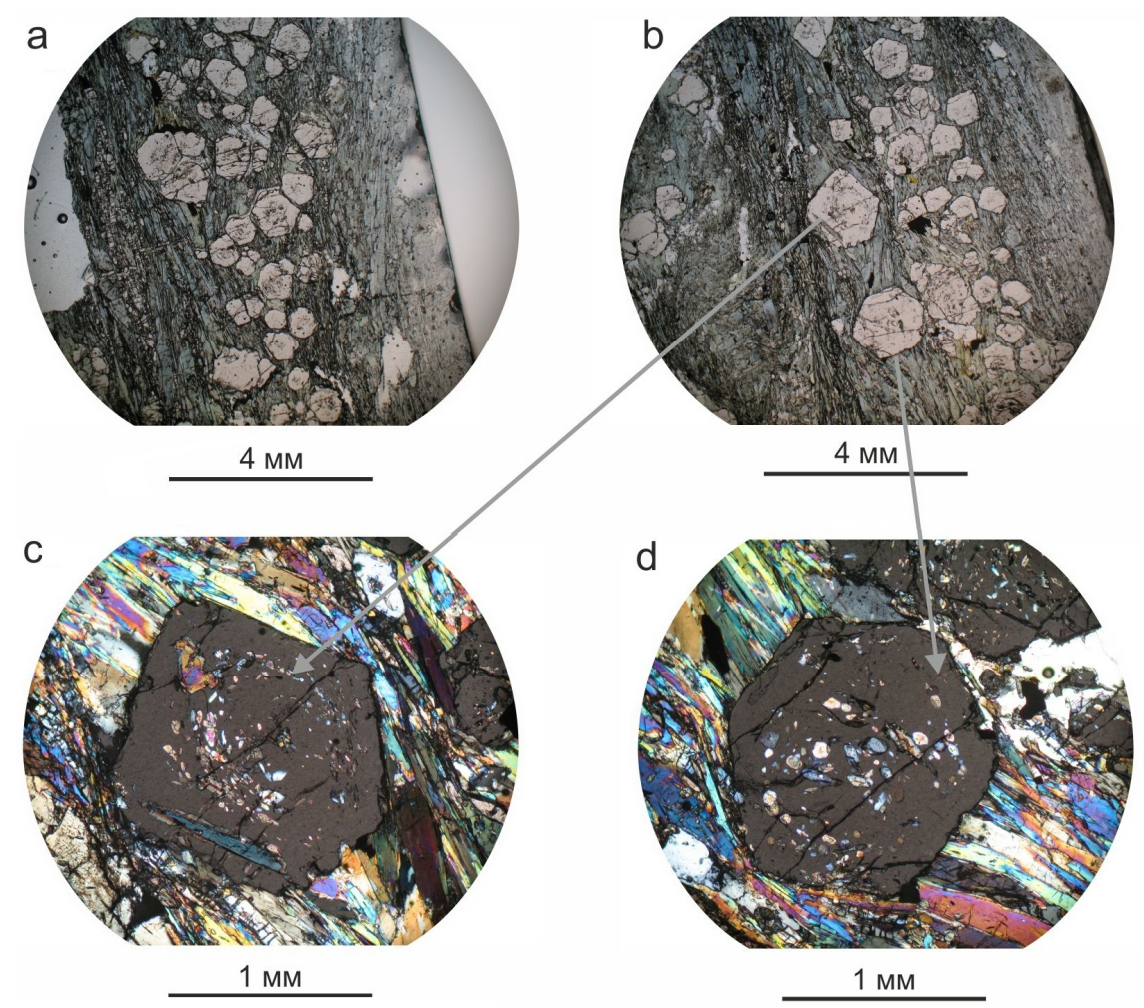

Puc. 4. Структурно-текстурные особенности тектонитов из северной части ПРСЗ Заангарья, Енисейского кряжа, обусловленные сегрегационным перераспределением материала в условиях регионального сдвига: $a-b$ - поздние сегрегационные обособления линзовидно-полосчатой морфологии существенно гранат-амфиболовых агрегатов, николи параллельны; $c-d-$ реликтовые включения глаукофана, альбита, фенгита и эпидота в порфиробластах граната, николи скрещены (б). 
Этапы докембрийской эволюции пород

Ангаро-Канский блок. Анализ геохронологических данных и датировок, полученных при изучении гнейсов ПРСЗ, позволил выделить несколько этапов деформационно-метаморфических преобразований в последовательности тектонических событий в докембрийской эволюции Южно-Енисейского кряжа в интервале от позднего палеопротерозоя до венда.

Первый этап формирования реликтовых гнейсов ( 1,73 млрд лет) соответствует времени проявления гранулит-амфиболитового метаморфизма пород. Эти датировки хорошо согласуются с возрастом формирования аллохтонных гиперстен-ортоклазовых гранитов - чарнокитов (кузеевитов) Ангаро-Канского выступа (1,73 млрд лет; [53]). Этот этап фиксирует завершение становления структуры Сибирского кратона в составе суперконтинента Нуна.

На втором этапе в результате растяжения коры, отвечающего предполагаемому распаду Нуны, эти породы подверглись прогрессивному динамометаморфизму с трансформацией от реликтовых к бластомилонитовым гнейсам и образованием комплексов высокобарических тектонитов. Эти процессы контролировались системой дискретных сдвиговых плоскостей и зон деформаций, обусловивших многократную деструкцию пород с тремя пиками $1,54,1,38$ и 1,25 млрд лет. Поздние деформации мезопротерозойской тектонической активизации в регионе, связанные с коллизией мезопротерозойских террейнов и формированием Родинии, произошли в интервале 1,171,03 млрд лет назад [25]. Это хорошо согласуется с эволюцией Гренвильского пояса в Лаврентии, являющейся ядром Родинии, диапазон развития которого охватывал от 1,8 до 1,0 млрд лет с наиболее значительными коллизионными процессами в интервале $1,19-0,98$ млрд лет назад [54].

Заключительный импульс динамометаморфических структурно-вещественных преобразований, приуроченных к ПРСЗ, проявлен в эдиакарии (венде), в узком диапазоне времени 615-603 млн лет назад. Возраст этих тектонотермальных событий маркирует завершающий этап неопротерозойской истории Енисейского кряжа, связанный с аккрецией Исаковского и Предивинского островодужных террейнов к западной окраине Сибирского кратона. Эти результаты согласуются с оценками возраста метаморфических пород Северо-Западного Присаянья (Канский блок и Арзыбейский террейн) [55], входящих совместно с Енисейским кряжем в состав Саяно-Енисейского аккреционного пояса.

Заангарье. Совокупность имеющихся датировок цирконов по магматическим комплексам Исаковского террейна $(701,6 \pm 8,4 ; 697,2 \pm 3,6 ; 691,8 \pm 8,8 ; 682 \pm 13$ млн лет) в Заангарье Енисейского кряжа [33, 56, 49, 57-59] совместно с датировками вулканитов Предивинского террейна, расположенного на юге Енисейского кряжа (637 $\pm 5,7$ млн лет) [60], указывают на формирование офиолитов и островных дуг Приенисейской зоны в интервале 700-640 млн лет. В последовательности тек- тонических событий в эволюции Енисейского кряжа изученные проявления основного магматизма могли отражать различные этапы растяжения вдоль западной окраины Сибирского кратона [61]. Образование более примитивных по химическому составу базальтов происходило на начальных этапах спрединга, когда плавлению подвергались верхние горизонты деплетированной мантии. А более высокотитанистые базальты образовались как продукты плавления обогащенного мантийного субстрата (менее истощенных горизонтов мантии) на более поздних этапах спрединга.

В конце неопротерозоя в диапазоне времени от 640 до 600 млн лет океаническая литосфера, фрагментом которой являлись базиты Исаковского террейна, субдуцировала под активную окраину Сибирского континента. Об этом свидетельствует обнаружение в регионе эксгумированных блоков с проявлениями глаукофансланцевого метаморфизма - метаморфизованных членов офиолитовых разрезов - формирующихся в зоне палеосубдукции и являющихся ее прямым индикатором. Современными оценками ${ }^{40} \mathrm{Ar} /{ }^{39} \mathrm{Ar}$ возрастов фенгитов и скоростей погружения и эксгумации глаукофансланцевых пород, полученными с использованием in situ ультрафиолетовой (UV) лазерной абляции, показано, что прогрессивная (погружение) и регрессивная (эксгумация) стадии субдукции в интенсивно деформированных тектонических зонах имеют разрыв во времени от 20 до 38 млн лет [62]. С учетом этих данных предполагаемый возраст процессов субдукции (погружения) базитов Исаковского террейна, ответственных за формирование глаукофановых сланцев, может отвечать интервалу от 640 до 620 млн лет. Это согласуется со временем формирования ряда высокобарических продуктов процессов субдукции (например, в Куртушибинском глаукофансланцевом и Северомуйском эклогитовом комплексах) в Центрально-Азиатском подвижном поясе [63].

На постсубдукционном этапе при эксгумации глаукофановые сланцы попадали в Приенисейскую сдвиговую зону, где подвергались интенсивным деформациям с полной перекристаллизацией субстрата и образованием новых высокобарических минеральных парагенезисов. В результате изотопно-геохронологического датирования биотитов и мусковитов из Grt-PlBt-Ms-Kfs-Qz тектоносланцев было установлено время наиболее позднего импульса динамометаморфических структурно-вещественных преобразований, которое произошло в эдиакарии (венде), в узком диапазоне времени 595-608 млн лет назад [51]. Выявленный синхронный этап вендских деформационнометаморфических событий в северном и южном сегментах ПРСЗ маркирует завершающую стадию неопротерозойской истории Енисейского кряжа, связанную с интенсивной тектонической переработкой пород меланжа шовной зоны после проявления аккреционно-субдукционных процессов в регионе. Эти результаты согласуются с оценками возраста метаморфических пород Северо-Западного Присаянья (Канский, Арзыбейский и Дербинский блоки) [44, 55], 
входящих совместно с Енисейским кряжем в состав Саяно-Енисейского аккреционного пояса.

\section{Химизм минералов}

Химический состав минеральных фаз установлен с помощью ренгеноспектрального микроанализатора Jeol JXA-8100 в ИГМ CO РАН (Новосибирск) по методике, представленной в работе [64]. Аналитические данные, использованные для геотермобарометрических определений, приведены в табл. 1-3. Для амфиболов Заангарья общее количество $\mathrm{FeO}$ пересчитано на содержания $\mathrm{FeO}$ и $\mathrm{Fe}_{2} \mathrm{O}_{3}$ с учетом стехиометрии [65]. Расчеты составов катионов, включающие стехиометрическую оценку содержания $\mathrm{Fe}^{3+}$, проводились с использованием программы MFC, доступной на сайте компании JEOL: http://cub.geoloweb.ch/.

Ангаро-Канский блок. Компонентный состав гранатов в метапелитах варьирует в диапазоне: $\mathrm{Alm}_{57-72}$, $\operatorname{Prp}_{16-36}, \mathrm{Grs}_{5-10}, \mathrm{Sps}_{1-5}$. Исходные метаморфические породы енисейской серии отличаются более железистыми составами гранатов $\left(\mathrm{X}_{\mathrm{Fe}}=0,7-0,82\right)$ и биотитов $\left(\mathrm{X}_{\mathrm{Fe}}=0,35-0,5\right)$ в сравнении с менее железистыми гранатами $\left(\mathrm{X}_{\mathrm{Fe}}=0,61-0,69\right)$ и биотитами $\left(\mathrm{X}_{\mathrm{Fe}}=0,24-0,3\right)$ канской серии, т.е. имеется положительная корреляция между составами пород и минералов. В зоне сдвиговых деформаций для бластомилонитов характерны более низкие содержания анортитового минала $\left(\mathrm{X}_{\mathrm{An}}=0,26\right.$ vs $\left.\mathrm{X}_{\mathrm{An}}=0,38\right)$ в плагиоклазах наряду с несколько пониженными концентрациями альмандинового (Alm) и спессартинового (Sps) компонента при более существенном повышении содержания гроссуляра (Grs) в гранатах в отличие от недеформированных пород (табл. 1). Слабое уменьшение железистости и содержания Sps в перекристаллизованных гранатах в зонах интенсивных деформаций может быть связано с незначительным увеличением температуры; а существенное повышение содержания Grs компонента граната с одновременным уменьшением $\mathrm{X}_{\mathrm{An}}$ составляющей в плагиоклазах определяется ростом давления. Это свидетельствует о проявлении в зонах разломов более высокобарического метаморфизма [66].

Заангарье. Компонентный состав гранатов в метабазитах пиковой ассоциации варьирует в диапазоне: $\mathrm{Alm}_{55-66}, \quad \operatorname{Prp}_{5-11}, \mathrm{Grs}_{22-32}, \mathrm{Sps}_{5-9}$, с железистостью $\left(\mathrm{X}_{\mathrm{Fe}}=0,84-0,92\right)$ (табл. 2). Амфибол представлен роговой обманкой с высокой железистостью $\left(\mathrm{X}_{\mathrm{Fe}}=0,34\right.$ 0,53), реже барруазитом с повышенным содержанием $\mathrm{Na}_{2} \mathrm{O}$ (до 2,8 мас\%) (рис. 5). Плагиоклаз относится к альбит-олигоклазу с содержанием $\mathrm{X}_{\mathrm{An}}=\mathrm{Ca} /(\mathrm{Ca}+\mathrm{Na}+\mathrm{K})$ $=0,04-0,17$. Для мусковита характерны высокие содержания фенгитового компонента (3,4-3,5 Si в ф.к.) и суммы $\mathrm{FeO}+\mathrm{MgO}$ (до 5,5 мас.\%) при незначительных изменениях парагонитовой составляющей $\left(\mathrm{X}_{\mathrm{Na}}=0,03-\right.$ 0,08). Железистость хлорита варьирует от 0,34 до 0,49. Карбонаты представлены кальцитом с содержанием $\mathrm{FeO}$ до 2,8 мас.\% и $\mathrm{MgO}$ до 1,6 мас.\% и железистым (FеO до 10 мас.\%) доломитом. Составы акцессорных эпидота, титанита, ильменита и рутила близки к стехиометрическим формулам.

Реликтовые включения глаукофана с максимальным содержанием $\mathrm{Na}_{2} \mathrm{O}$ до 7,76 мас.\% при содержании $\mathrm{CaO}=0,51$ мас.\% были впервые обнаружены в зернах граната (рис. 4) и титанита. Натровые амфиболы представлены преимущественно глаукофаном и ферроглаукофаном (табл. 2; рис. 5). Содержание $\mathrm{Na}(\mathrm{M} 4)$ в них варьирует от 1,62 до 1,86 ф.е., железистость - от 0,32 до 0,57. Иногда наблюдается зональность, проявленная в изменении окраски и увеличении общей железистости, что может быть связано с процессом эксгумации пород. Мусковиты характеризуются пониженными содержаниями фенгитового компонента $(3,35 \mathrm{Si}$ в ф.к.) и парагонитовой составляющей $\left(\mathrm{X}_{\mathrm{Na}}=0,01\right)$, и повышенными концентрациями суммы $\mathrm{FeO}+\mathrm{MgO}$ (до 6,86 мас.\%) по сравнению с составами муковитов в пиковой генерации. Ранний плагиоклаз представлен альбитом, содержащим менее 1 $\%$ анортитового минала (табл. 3). Химический состав граната на контакте с реликтовыми минералами отличается повышенной железистостью $\left(\mathrm{X}_{\mathrm{Fe}}=0,93-0,95\right)$ по сравнению с гранатом из пиковой генерации.

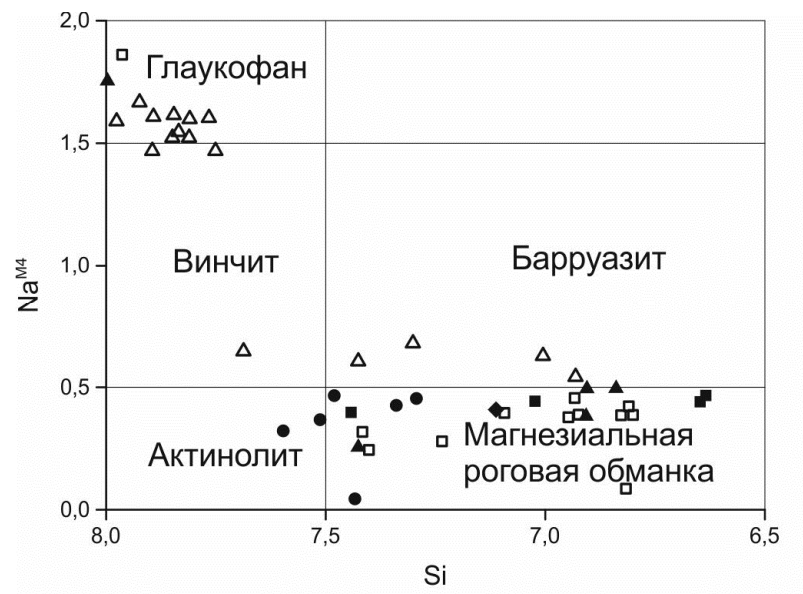

Рис. 5. Классификационные диаграммы $\mathrm{Si}-\mathrm{Na}^{\mathrm{M} 4}$ (а) и $\mathrm{Fe}^{3+} /\left(\mathrm{Fe}^{3+}+\mathrm{Al}\right)-\mathrm{Fe}^{2+} /\left(\mathrm{Fe}^{2+}+\mathrm{Mg}\right)$ (б), показывающие химический состав амфиболов из метабазитовых тектонитов. 


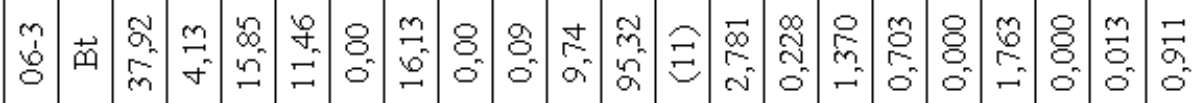

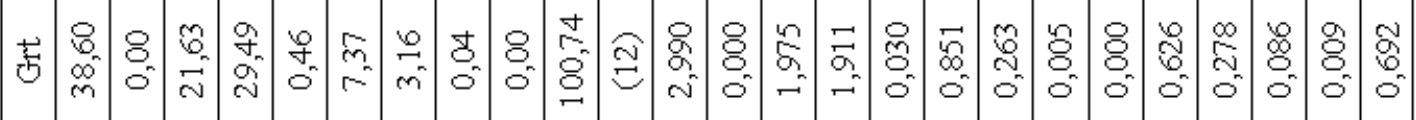

\begin{tabular}{|c|c|c|c|c|c|c|c|c|c|c|c|c|c|c|c|c|c|c|c|c|c|c|c|c|c|c|}
\hline \multirow{3}{*}{$\begin{array}{l}\infty \\
\text { i } \\
\end{array}$} & $\overrightarrow{\rho_{1}}$ & 8 & 8 & $\stackrel{\square}{\square}$ & 6 & 8 & 8 & 要 & 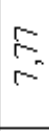 & $\stackrel{\square}{\sigma}$ & $\frac{8}{6}$ & 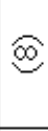 & 8 & 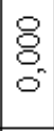 & $\frac{\infty}{m}$ & $\begin{array}{l}\mathscr{g} \\
6 \\
6\end{array}$ & $\stackrel{8}{8}$ & $\begin{array}{l}9 \\
6 \\
6\end{array}$ & $\frac{d}{m}$ & 8 & 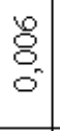 & & & & & $\stackrel{m}{\sigma}$ \\
\hline & 苟 & 6 & $\begin{array}{l}\text { g } \\
\text { v }\end{array}$ & 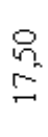 & 9 & 8 & 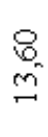 & $\stackrel{8}{8}$ & $\stackrel{F}{\sigma}$ & $\stackrel{M}{m}$ & $\begin{array}{l}\mathrm{d} \\
\mathrm{d}\end{array}$ & $\overparen{\Xi}$ & 8 & $\underset{\mathrm{J}}{\mathrm{J}}$ & $m_{n}$ & 8 & 8 & $\begin{array}{c}\infty \\
\vec{\sigma} \\
-\end{array}$ & 8 & $\stackrel{6}{6}$ & $\frac{8}{8}$ & & & & & 0 \\
\hline & $\stackrel{\square}{\square}$ & $\begin{array}{c}\infty \\
\infty \\
\infty\end{array}$ & 8 & $\frac{m}{2}$ & $g_{0}$ & $\stackrel{\rho}{\rho}$ & $m_{m}$ & $\underset{Z}{\mathbb{Z}}$ & $\stackrel{8}{6}$ & $\stackrel{8}{8}$ & $\begin{array}{c}6 \\
6 \\
6\end{array}$ & $\vartheta$ & 9 & $\begin{array}{l}8 \\
6 \\
6\end{array}$ & $\underset{8}{\sigma}$ & $\begin{array}{c}\infty \\
\sigma_{2} \\
-\end{array} \mid$ & $\underset{8}{d}$ & $\begin{array}{c}8 \\
6\end{array}$ & $\frac{0}{\sigma}$ & $\frac{5}{8}$ & $\begin{array}{l}8 \\
6\end{array}$ & 8 & $\begin{array}{l}\$ \\
\varnothing\end{array}$ & $\stackrel{\infty}{6}$ & 0 & 8 \\
\hline \multirow{3}{*}{ 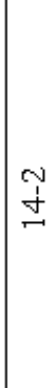 } & $\overrightarrow{\beta_{1}}$ & $\stackrel{ \pm}{6}$ & $\begin{array}{l}8 \\
6\end{array}$ & $\frac{\mathrm{d}}{\mathrm{d}}$ & 8 & $\stackrel{8}{8}$ & 8 & 6 & $\sqrt{n}$ & $\stackrel{m}{\rightleftarrows}$ & $\begin{array}{l}\infty \\
g \\
g\end{array}$ & 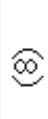 & $g$ & 8 & $\underline{\omega_{2}}$ & $\begin{array}{l}9 \\
6 \\
6\end{array}$ & $\begin{array}{l}8 \\
8\end{array}$ & $\begin{array}{l}8 \\
6 \\
6\end{array}$ & $\begin{array}{l}8 \\
0 \\
0\end{array}$ & 8 & 8 & & & & & $\infty$ \\
\hline & 芥 & 6 & $\infty$ & $\underset{\cdots}{\infty}$ & $\underset{6}{-}$ & 8 & $\stackrel{\varrho}{\varrho}$ & $\frac{8}{8}$ & $\stackrel{\infty}{\sigma}$ & $\begin{array}{c}\infty \\
m \\
0\end{array}$ & $\begin{array}{l}\infty \\
6 \\
6 \\
6\end{array}$ & 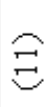 & 8 & $\underset{8}{g}$ & $\begin{array}{c}0 \\
6 \\
-2 \\
-2\end{array}$ & $\vec{\sigma}$ & 8 & $\begin{array}{c}0 \\
\mathrm{v} \\
\cdots\end{array}$ & $\begin{array}{l}8 \\
8\end{array}$ & $\begin{array}{l}\infty \\
\varrho \\
\varrho\end{array}$ & $\frac{\wp}{6}$ & & & & & m \\
\hline & 莺 & $\varrho_{\infty}$ & 8 & $\frac{m}{m}$ & $\stackrel{9}{\stackrel{9}{m}}$ & 守 & 8 & $\vec{\sigma}$ & 8 & 8 & $\stackrel{8}{8}$ & $\widehat{\sigma}$ & $\frac{5}{g_{n}}$ & 8 & 8 & $\left|\begin{array}{c}0 \\
\Xi \\
\sigma \\
\sigma\end{array}\right|$ & $\frac{8}{8}$ & 6 & $\frac{8}{6}$ & 8 & $\begin{array}{c}8 \\
6 \\
6\end{array}$ & 8 & 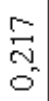 & 6 & 6 & 6 \\
\hline
\end{tabular}

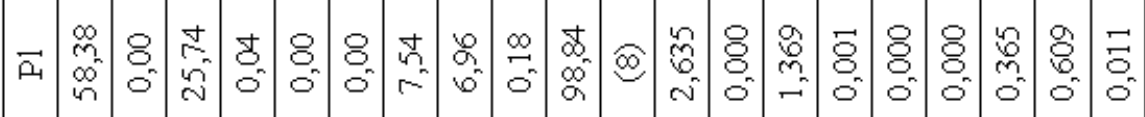

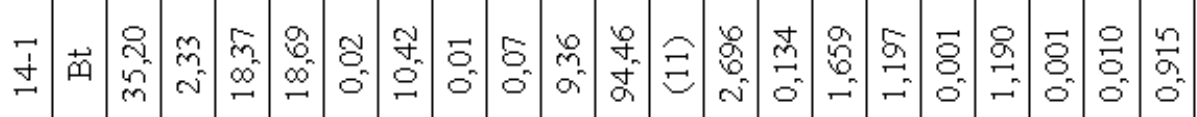

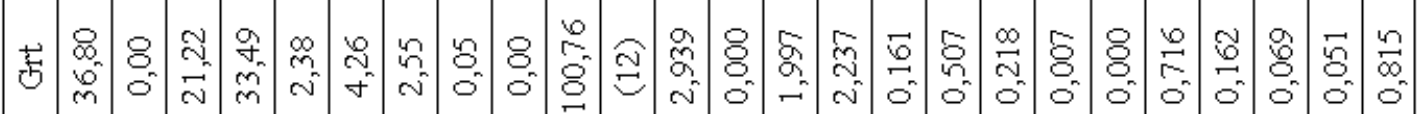

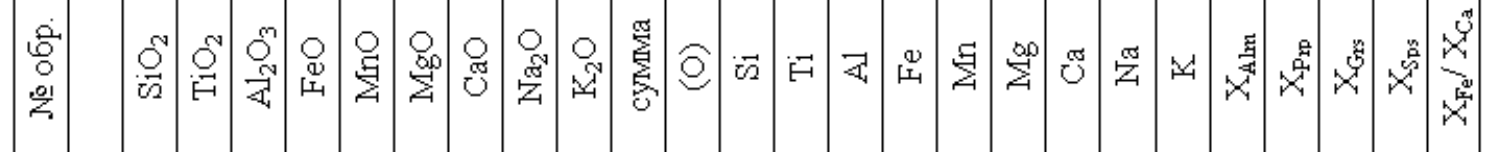




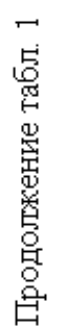

\begin{tabular}{|c|c|c|c|c|c|c|c|c|c|c|c|c|c|c|c|c|c|c|c|c|c|c|c|c|c|}
\hline \multirow{3}{*}{$\overrightarrow{8}$} & $\overrightarrow{\mu_{1}}$ & $\begin{array}{l}\vec{\Xi} \\
\overrightarrow{6}\end{array}$ & $\begin{array}{c}8 \\
\circ\end{array}$ & 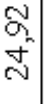 & $\stackrel{8}{\circ}$ & $\stackrel{\delta}{0}_{0}$ & $\stackrel{8}{8}$ & $\begin{array}{l}F_{n} \\
n^{\prime}\end{array}$ & $\begin{array}{l}9 \\
\infty_{0}^{\circ}\end{array}$ & $\begin{array}{l}\mathscr{8} \\
\stackrel{0}{\circ}\end{array}$ & $\begin{array}{l}\frac{1}{9} \\
\stackrel{2}{\sigma}\end{array}$ & $\widehat{\infty}$ & 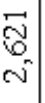 & $\begin{array}{l}8 \\
8 \\
\circ\end{array}$ & 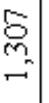 & $\begin{array}{c}\tilde{8} \\
\tilde{\delta}_{0}\end{array}$ & $\begin{array}{l}8 \\
8 \\
\circ\end{array}$ & $\begin{array}{l}8 \\
8 \\
\circ\end{array}$ & $\begin{array}{l}\underset{J}{\mathrm{~N}} \\
\stackrel{0}{\circ}\end{array}$ & $\begin{array}{l}\text { o } \\
\text { o. } \\
0^{-}\end{array}$ & $\begin{array}{l}8 \\
8 \\
0\end{array}$ & & & & \\
\hline & 䒢 & $\vec{m}$ & $\begin{array}{l}\infty \\
\infty \\
v^{2}\end{array}$ & $\begin{array}{l}\alpha \\
\alpha \\
n \\
\end{array}$ & \begin{tabular}{l}
$\stackrel{\Upsilon}{\circ}$ \\
\hdashline \\
\hdashline
\end{tabular} & $\begin{array}{l}{ }_{0} \\
\circ\end{array}$ & 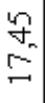 & $\stackrel{5}{\circ}$ & $\begin{array}{l}\mathscr{8} \\
\circ \\
\circ\end{array}$ & $\begin{array}{c} \pm \\
\sigma^{\prime}\end{array}$ & \begin{tabular}{l}
$a$ \\
\multirow{2}{\alpha}{} \\
$\alpha$
\end{tabular} & $\hat{\Xi}$ & $\stackrel{m}{\approx}$ & $\begin{array}{l}0 \\
0 \\
0 \\
0 \\
0\end{array}$ & 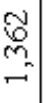 & $\begin{array}{l}0 \\
8 \\
0 \\
0 \\
0\end{array}$ & & $\begin{array}{l}\stackrel{\infty}{\infty} \\
\infty \\
- \\
-\end{array}$ & $\stackrel{8}{8}$ & $\vec{\circ}$ & $\begin{array}{c}\mathscr{O} \\
\alpha \\
\sigma\end{array}$ & & & & \\
\hline & 苛 & $\begin{array}{c}\infty \\
\stackrel{n}{m} \\
m^{n}\end{array}$ & $\stackrel{8}{8}$ & $\begin{array}{l}\vec{\Omega} \\
\vec{N}\end{array}$ & $\begin{array}{l}0 \\
0 \\
0 \\
0 \\
\end{array}$ & $\vec{n}$ & $\overbrace{\circ}^{\circ}$ & $\begin{array}{l}\vec{v} \\
\sim \\
v\end{array}$ & $\stackrel{5}{\circ}$ & 8 & $\begin{array}{l}\mathscr{\infty} \\
\sigma^{\prime} \\
\alpha\end{array}$ & $\stackrel{\overbrace{}}{\Xi}$ & $\begin{array}{l}8 \\
\dot{8} \\
m\end{array}$ & $\begin{array}{l}8 \\
8 \\
0\end{array}$ & $\begin{array}{l}\$ \\
\stackrel{\$}{2} \\
- \\
-\end{array}$ & \begin{tabular}{l}
8 \\
\hdashline \\
-2
\end{tabular} & 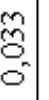 & $\begin{array}{l}\mathbb{D} \\
\stackrel{-}{-} \\
-\end{array}$ & $\begin{array}{l}\mathcal{N} \\
\stackrel{0}{0} \\
0\end{array}$ & $\stackrel{8}{8}$ & $\begin{array}{l}8 \\
8 \\
0\end{array}$ & & $\begin{array}{c}0 \\
0 \\
0\end{array}$ & $\overrightarrow{\sigma_{0}}$ & $\overline{0}$ \\
\hline & & $\begin{array}{l}m \\
\vec{b} \\
=\end{array}$ & & $\overrightarrow{\mathbb{N}^{\prime}}$ & & 8 & 8 & $\begin{array}{l}n \\
6 \\
6\end{array}$ & $\begin{array}{c}\infty \\
\infty \\
\infty\end{array} \mid$ & $\underset{0}{\stackrel{ \pm}{0}}$ & & $\widehat{\infty}$ & $\stackrel{2}{2}$ & $\begin{array}{l}8 \\
\circ \\
\circ\end{array}$ & $\begin{array}{l}\infty \\
\widetilde{v} \\
- \\
-\end{array}$ & $\overline{8}_{0}$ & & $\begin{array}{l}8 \\
8 \\
\circ\end{array}$ & $\begin{array}{c}\vec{m} \\
\hat{m}^{\prime}\end{array}$ & $\begin{array}{l}\hat{6} \\
6 \\
\circ \\
\circ\end{array}$ & $\begin{array}{l}\infty \\
8 \\
0 \\
0\end{array}$ & & & & \\
\hline
\end{tabular}

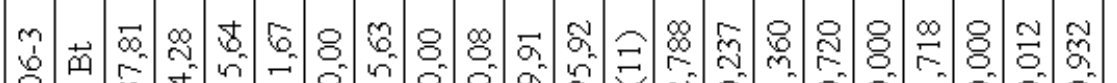

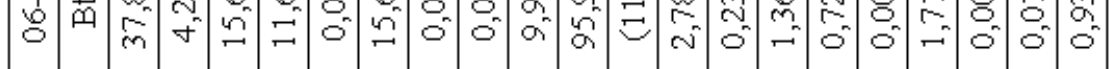

n

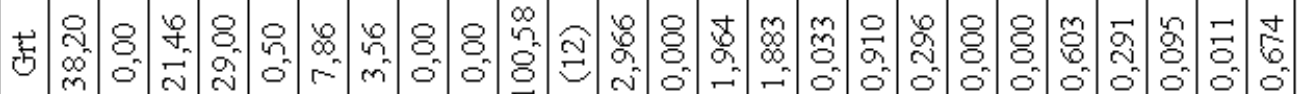

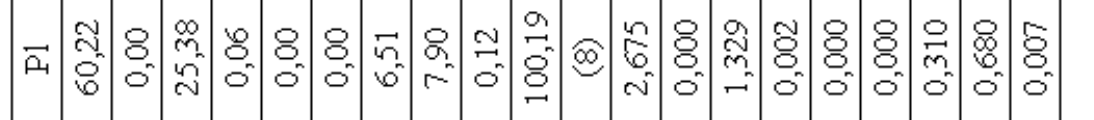

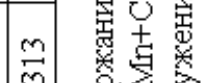

m.

鲶

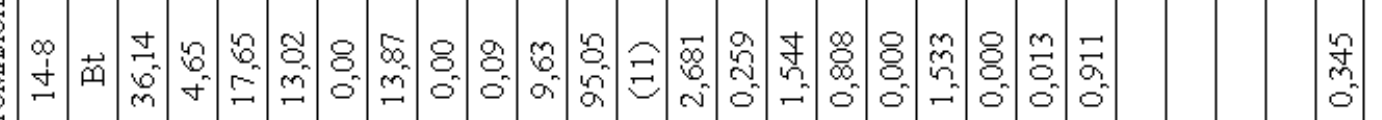

品

齐密

密兽

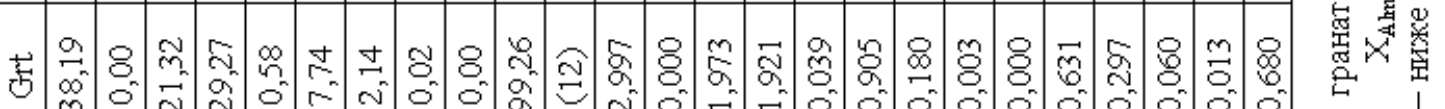

营名

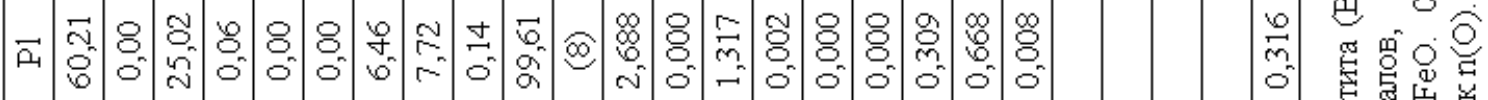

密焉

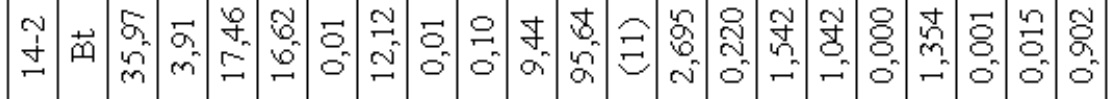

怂

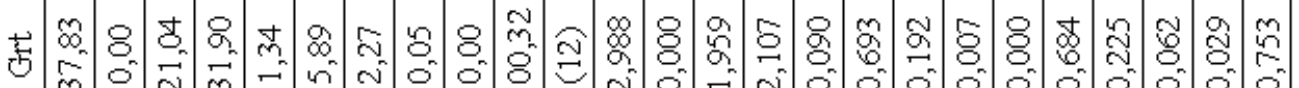

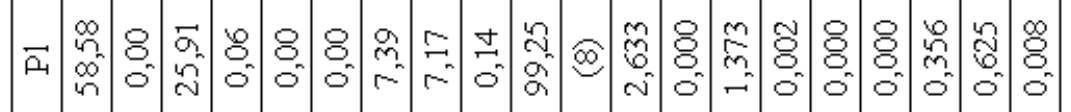

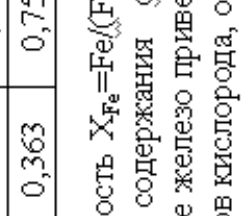

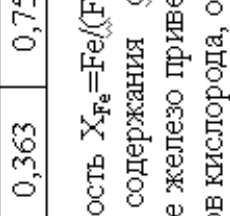

总 总

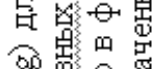

敋员䍃

古频䧟。

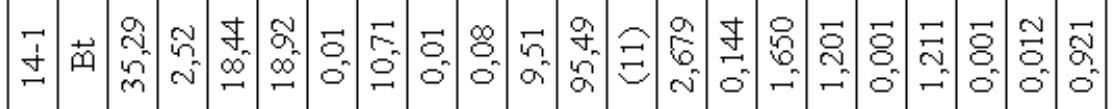

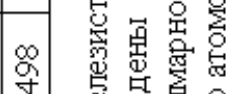

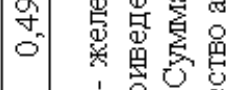

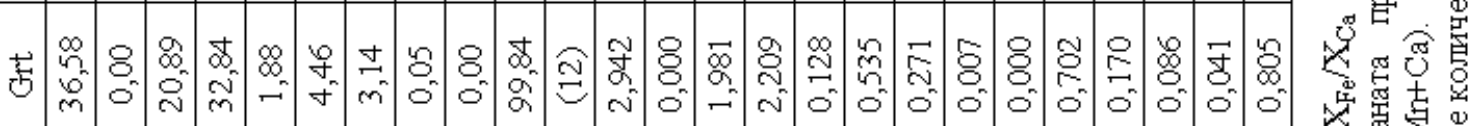

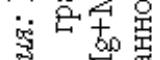

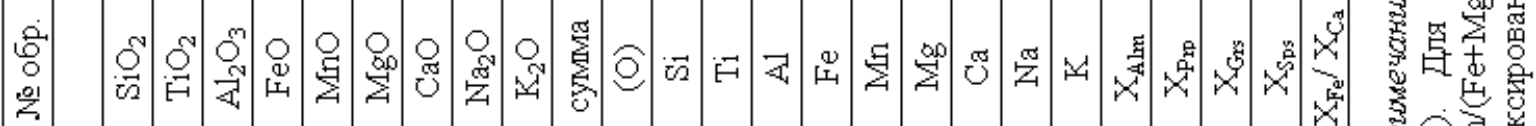
象鱼兽 
Таблица 2

Химический состав и структурные формуль амфиболов метабазитов обр. 3 и 11, используемые для построения Р-T псевдосечений

\begin{tabular}{|c|c|c|c|c|}
\hline $\begin{array}{l}\text { Образец } \\
\text { Минерал } \\
\text { Позиция }\end{array}$ & $\begin{array}{c}11 \\
\text { Глаукофан } \\
\text { включение }\end{array}$ & $\begin{array}{c}11 \\
\text { Актинолит } \\
\text { матрикс }\end{array}$ & $\begin{array}{c}3 \\
\text { Глаукофан } \\
\text { включение }\end{array}$ & $\begin{array}{c}3 \\
\text { Hrb } \\
\text { матрикс }\end{array}$ \\
\hline $\begin{array}{c}\mathrm{SiO}_{2} \\
\mathrm{TiO}_{2} \\
\mathrm{Al}_{2} \mathrm{O}_{3} \\
\mathrm{Fe}_{2} \mathrm{O}_{3} \\
\mathrm{FeO} \\
\mathrm{MnO} \\
\mathrm{MgO} \\
\mathrm{CaO} \\
\mathrm{Na} \mathrm{Na}_{2} \mathrm{O} \\
\mathrm{K}_{2} \mathrm{O}\end{array}$ & $\begin{array}{c}55,38 \\
0,03 \\
7,71 \\
2,86 \\
16,41 \\
0,13 \\
6,98 \\
0,52 \\
7,76 \\
0,02\end{array}$ & $\begin{array}{c}52,87 \\
0,14 \\
7,83 \\
2,77 \\
10,42 \\
0,16 \\
13,79 \\
8,21 \\
2,58 \\
0,22\end{array}$ & $\begin{array}{c}54,70 \\
0,20 \\
5,28 \\
6,06 \\
15,68 \\
0,18 \\
6,74 \\
1,54 \\
6,66 \\
0,03\end{array}$ & $\begin{array}{c}46,60 \\
0,39 \\
12,16 \\
2,63 \\
15,32 \\
0,25 \\
8,67 \\
9,04 \\
2,80 \\
0,20\end{array}$ \\
\hline Сумма & 97,81 & 98,99 & 97,07 & 98,06 \\
\hline$(0)$ & 23 & 23 & 23 & 23 \\
\hline $\begin{array}{c}\mathrm{Si} \\
\mathrm{Ti} \\
\mathrm{Al} \\
\mathrm{Fe}^{3+} \\
\mathrm{Fe}^{2+} \\
\mathrm{Mn} \\
\mathrm{Mg} \\
\mathrm{Ca} \\
\mathrm{Na} \\
\mathrm{K}\end{array}$ & $\begin{array}{c}7,96 \\
- \\
1,31 \\
0,31 \\
1,97 \\
0,02 \\
1,50 \\
0,08 \\
2,16 \\
- \\
\end{array}$ & $\begin{array}{l}7,43 \\
0,02 \\
1,30 \\
0,29 \\
1,22 \\
0,02 \\
2,89 \\
1,24 \\
0,70 \\
0,04 \\
\end{array}$ & $\begin{array}{l}8,00 \\
0,02 \\
0,91 \\
0,67 \\
1,92 \\
0,02 \\
1,47 \\
0,24 \\
1,89 \\
0,01 \\
\end{array}$ & $\begin{array}{l}6,84 \\
0,04 \\
2,10 \\
0,29 \\
1,88 \\
0,03 \\
1,90 \\
1,42 \\
0,80 \\
0,04 \\
\end{array}$ \\
\hline Сумма & 15,31 & 15,14 & 15,14 & 15,34 \\
\hline $\begin{array}{c}\mathrm{Fe}^{\mathrm{tot}} /\left(\mathrm{Fe}^{\mathrm{tot}}+\mathrm{Mg}\right) \\
\mathrm{Mg} /\left(\mathrm{Mg}+\mathrm{Fe}^{2+}\right) \\
\mathrm{XAl}(\mathrm{M} 2) \\
\mathrm{XCa}(\mathrm{M} 4) \\
\mathrm{XNa}(\mathrm{M} 4) \\
\mathrm{XNa}(\mathrm{A})\end{array}$ & $\begin{array}{l}0,60 \\
0,43 \\
0,63 \\
0,04 \\
0,93 \\
0,31\end{array}$ & $\begin{array}{l}0,34 \\
0,70 \\
0,36 \\
0,62 \\
0,30 \\
0,10\end{array}$ & $\begin{array}{l}0,64 \\
0,43 \\
0,45 \\
0,12 \\
0,88 \\
0,13\end{array}$ & $\begin{array}{l}0,53 \\
0,50 \\
0,47 \\
0,71 \\
0,25 \\
0,30\end{array}$ \\
\hline $\begin{array}{c}\mathrm{Si}(\mathrm{T} 12) \\
\mathrm{Al}^{\mathrm{IV}}(\mathrm{T} 1) \\
\Sigma\end{array}$ & $\begin{array}{l}7,96 \\
0,04 \\
8,00\end{array}$ & $\begin{array}{l}7,43 \\
0,58 \\
8,00\end{array}$ & $\begin{array}{l}8,00 \\
0,00 \\
8,00\end{array}$ & $\begin{array}{l}6,84 \\
1,16 \\
8,00\end{array}$ \\
\hline $\begin{array}{c}\mathrm{Al}^{\mathrm{VI}}(\mathrm{M} 2) \\
\mathrm{Fe}^{3+}(\mathrm{M} 2) \\
\mathrm{Ti}(\mathrm{M} 123) \\
\mathrm{Mg}(\mathrm{M} 123) \\
\mathrm{Fe}^{2+}(\mathrm{M} 123) \\
\mathrm{Mn}(\mathrm{M} 123) \\
\Sigma\end{array}$ & $\begin{array}{c}1,27 \\
0,31 \\
- \\
1,50 \\
1,93 \\
- \\
5,00\end{array}$ & $\begin{array}{c}0,72 \\
0,29 \\
0,02 \\
2,89 \\
1,09 \\
- \\
5,00\end{array}$ & $\begin{array}{l}0,91 \\
0,67 \\
0,02 \\
1,47 \\
1,92 \\
0,02 \\
5,00\end{array}$ & $\begin{array}{c}0,94 \\
0,29 \\
0,04 \\
1,90 \\
1,83 \\
- \\
5,00\end{array}$ \\
\hline $\begin{array}{c}\mathrm{Mn}(\mathrm{M} 4) \\
\mathrm{Fe}^{2+}(\mathrm{M} 4) \\
\mathrm{Ca}(\mathrm{M} 4) \\
\mathrm{Na}(\mathrm{M} 4) \\
\Sigma\end{array}$ & $\begin{array}{l}0,02 \\
0,05 \\
0,08 \\
1,86 \\
2,00\end{array}$ & $\begin{array}{l}0,02 \\
0,14 \\
1,24 \\
0,61 \\
2,00\end{array}$ & $\begin{array}{c}- \\
- \\
0,24 \\
1,76 \\
2,00\end{array}$ & $\begin{array}{l}0,03 \\
0,05 \\
1,42 \\
0,50 \\
2,00\end{array}$ \\
\hline $\begin{array}{c}\mathrm{Na}(\mathrm{A}) \\
\mathrm{K}(\mathrm{A}) \\
\square(\mathrm{A}) \\
\Sigma \\
\end{array}$ & $\begin{array}{c}0,31 \\
- \\
0,70 \\
1,00\end{array}$ & $\begin{array}{l}0,10 \\
0,04 \\
0,86 \\
1,00\end{array}$ & $\begin{array}{l}0,13 \\
0,01 \\
0,87 \\
1,00\end{array}$ & $\begin{array}{l}0,30 \\
0,04 \\
0,66 \\
1,00\end{array}$ \\
\hline
\end{tabular}


Таблица 3

Химический состав и структурные формуль минералов метабазитов обр. 3 и 11, используемые для построения $P-T$ псевдосечений

\begin{tabular}{|c|c|c|c|c|c|c|c|c|c|c|c|c|c|c|}
\hline $\begin{array}{c}\text { Образец } \\
\text { Минерал } \\
\text { Позиция }\end{array}$ & $\begin{array}{c}11 \\
\text { Grt } \\
\text { ядро }\end{array}$ & $\begin{array}{c}11 \\
\text { Grt } \\
\text { край }\end{array}$ & $\begin{array}{c}3 \\
\mathrm{Grt} \\
\text { ядро }\end{array}$ & $\begin{array}{c}3 \\
\text { Grt } \\
\text { край }\end{array}$ & $\begin{array}{c}11 \\
\text { Pl } \\
\text { вкл. }\end{array}$ & $\begin{array}{c}11 \\
\text { Ms } \\
\text { вкл. }\end{array}$ & $\begin{array}{c}11 \\
\text { Ер } \\
\text { вкл. }\end{array}$ & $\begin{array}{c}11 \\
\text { Chl } \\
\text { вкл. }\end{array}$ & $\begin{array}{c}11 \\
\text { Pl } \\
\text { матр. }\end{array}$ & $\begin{array}{c}3 \\
\text { Pl } \\
\text { вкл. }\end{array}$ & $\begin{array}{c}3 \\
\text { Еp } \\
\text { вкл. }\end{array}$ & $\begin{array}{c}3 \\
\text { Chl } \\
\text { вкл. }\end{array}$ & $\begin{array}{c}3 \\
\text { Pl } \\
\text { матр. }\end{array}$ & $\begin{array}{c}3 \\
\text { Ms } \\
\text { матр. }\end{array}$ \\
\hline $\mathrm{SiO}_{2}$ & 37,14 & 38,63 & 37,61 & 37,60 & 67,80 & 49,37 & 38,87 & 26,90 & 64,57 & 69,20 & 39,27 & 26,95 & 67,89 & 52,23 \\
\hline $\mathrm{TiO}_{2}$ & 0,14 & 0,15 & 0,10 & 0,12 & 0,02 & 0,21 & 0,11 & 0,06 & 0,11 & 0,02 & 0,15 & 0,12 & - & 0,22 \\
\hline $\mathrm{Al}_{2} \mathrm{O}_{3}$ & 20,41 & 20,65 & 20,24 & 20,13 & 19,39 & 27,37 & 24,94 & 20,68 & 21,89 & 18,08 & 27,22 & 21,15 & 98, 19 & 26,74 \\
\hline $\mathrm{Fe}_{2} \mathrm{O}_{3}$ & 2,03 & - & 0,83 & 0,79 & 0,19 & 0,91 & 11,94 & 0,21 & 0,10 & 0,13 & 8,12 & - & 0,12 & - \\
\hline $\mathrm{FeO}$ & 46, 26 & 63, 25 & 66, 27 & 50, 29 & - & 3,48 & 0,21 & 19,27 & - & - & 0,07 & 82, 19 & - & 2,36 \\
\hline & 1,88 & 2,16 & 1,99 & 1,43 & - & 0,01 & 0,22 & 0,07 & 0,09 & - & 0,06 & 0,06 & - & 0,01 \\
\hline $\mathrm{MgO}$ & 1,17 & 2,71 & 0,92 & 2,18 & 0,06 & 2,56 & 0,03 & 20,35 & 0,06 & - & 0,05 & 19,74 & 0,01 & 3,18 \\
\hline $\mathrm{CaO}$ & 95, 10 & 13, 10 & 68, 10 & 7,88 & 1,78 & 0,02 & 22,75 & 0,02 & 2,40 & 0,18 & 23,25 & 0,03 & 0,86 & 0,02 \\
\hline $\mathrm{Na}_{2} \mathrm{O}$ & - & 0,10 & - & 0,03 & 10,14 & 0,07 & 0,02 & - & 95, 10 & 12,33 & - & 0,01 & 11,10 & 0,30 \\
\hline $\mathrm{K}_{2} \mathrm{O}$ & 0,02 & 0,01 & 0,02 & - & 0,17 & 10,82 & 0,01 & 0,01 & 0,13 & 0,04 & - & 0,01 & 0,05 & 9,45 \\
\hline Сумма & 100,19 & 100,17 & 100,05 & 99,66 & 99,55 & 94,82 & 99,1 & 87,57 & 100,3 & 99,98 & 98,19 & 87,89 & 100,01 & 94,51 \\
\hline )) & 12 & 12 & 12 & 12 & 8 & 11 & 12,5 & 14 & 8 & 8 & 12,5 & 14 & 8 & 11 \\
\hline $\mathrm{Si}$ & 2,97 & 3,04 & 3,01 & 3,02 & 2,98 & 3,35 & 3,03 & 2,74 & 2,85 & 3,03 & 3,05 & 2,74 & 2,97 & 3,48 \\
\hline $\mathrm{Ti}$ & 0,01 & 0,01 & 0,01 & 0,01 & - & 0,01 & 0,01 & 0,01 & - & - & 0,01 & 0,01 & - & 0,01 \\
\hline $\mathrm{Al}$ & 1,92 & 1,92 & 1,91 & 1,91 & 1,00 & 2,19 & 2,29 & 2,49 & 1,14 & 0,93 & 2,49 & 2,54 & 1,03 & 2,10 \\
\hline $\mathrm{Fe}^{3+}$ & 0,12 & - & 0,05 & 0,05 & 0,01 & 0,05 & 0,70 & 0,02 & - & - & 0,47 & - & - & - \\
\hline $\mathrm{Fe}^{2+}$ & 1,77 & 1,69 & 1,85 & 1,98 & - & 0,20 & 0,01 & 1,64 & - & - & 0,01 & 1,69 & - & 0,13 \\
\hline $\mathrm{Mn}$ & 0,13 & 0,14 & 0,14 & 0,10 & - & - & 0,02 & 0,01 & - & - & - & 0,01 & - & - \\
\hline $\mathrm{Mg}$ & 0,14 & 0,32 & 0,11 & 0,26 & - & 0,26 & - & 3,09 & - & - & 0,01 & 2,99 & - & 0,32 \\
\hline $\mathrm{Ca}$ & 0,94 & 0,86 & 0,92 & 0,68 & 0,08 & - & 1,90 & - & 0,11 & 0,01 & 1,93 & - & 0,04 & - \\
\hline $\mathrm{Na}$ & - & 0,02 & - & - & 0,86 & 0,01 & - & - & 0,94 & 1,05 & - & - & 0,94 & 0,04 \\
\hline $\mathrm{K}$ & - & - & - & - & 0,01 & 0,94 & - & - & 0,01 & - & - & - & 0,00 & 0,80 \\
\hline Сумма & 8,00 & 8,00 & 8,00 & 8,00 & 4,95 & 7,00 & 7,97 & 10,00 & 5,05 & 5,03 & 7,97 & 9,98 & 4,99 & 6,881 \\
\hline $\mathrm{Fe}^{\mathrm{tot}} /\left(\mathrm{Fe}^{\mathrm{tot}}+\mathrm{Mg}\right.$ & 0,93 & 0,84 & 0,95 & 0,89 & - & - & - & - & - & - & - & - & - & - \\
\hline $\mathrm{Ca} /\left(\mathrm{Fe}^{\mathrm{tot}}+\mathrm{Mg}+\right.$ & 0,32 & 0,30 & 0,31 & 0,23 & - & - & - & - & - & - & - & - & - & - \\
\hline$\tilde{\mathrm{XFe}}$ & 0,61 & 0,56 & 0,62 & 0,66 & - & 0,43 & - & 0,35 & - & - & - & 0,36 & - & 0,29 \\
\hline $\mathrm{XCa}$ & 0,30 & 0,28 & 0,30 & 0,22 & - & - & - & - & - & - & - & - & - & - \\
\hline $\mathrm{XMg}$ & 0,04 & 0,11 & 0,04 & 0,09 & - & 0,57 & - & 0,65 & - & - & - & 0,64 & - & 0,71 \\
\hline XMn & 0,04 & 0,05 & 0,04 & 0,03 & - & - & - & - & - & - & - & - & - & - \\
\hline
\end{tabular}

Примечания: символы минералов приняты по [45]. Вкл. - включение в гранате, матр. - матрикс.

Компонентный состав граната в метапелитовых тектонитах варьирует в более широком диапазоне: Alm $_{60-76}, \operatorname{Prp}_{4-9}$, Grs $_{14-28}, \operatorname{Sps}_{1-7}$ с незначительным изменением железистости $\left(\mathrm{X}_{\mathrm{Fe}}=0,88-0,95\right)$. Состав плагиоклаза и железистость биотита варьируют в следущих диапазонах - $\left(\mathrm{X}_{\mathrm{An}}=0,14-0,34\right)$ и $\left(\mathrm{X}_{\mathrm{Fe}}=0,55-0,71\right)$, соответственно. Для мусковита характерны высокие содержания фенгитового компонента $(3,3-3,4 \mathrm{Si}$ в ф.к.) [50].

\section{Краткие выводы}

В пределах Приенисейской региональной сдвиговой зоны (ПРС3) Енисейского кряжа изучены метапелиты и метабазиты, подвергшиеся интенсивным деформациям с перекристаллизацией субстрата и образованием тектонитов. Наложение более поздних минеральных ассоциаций на ранние в ходе разных геодинамических событий четко фиксируется по геоло- го-структурным особенностям доменов сильно- и слабодеформированных пород, реологии пород, реакционным микротекстурам, химической зональности минералов и изотопным датировкам. Такие индикаторные признаки свидетельствуют о полиметаморфической истории пород, контролируемой разными тектоническими механизмами. Неоднородность метаморфических преобразований и выявленные особенности реологии пород, включающие процессы фрагментации в системе «гнейсы - бластомилониты» и структурно-текстурные особенности бластомилонитов, обусловленные сегрегационным перераспределением материала в условиях регионального сдвига, указывают на возможность генерации сверхдавлений и роста температуры в шовных зонах земной коры. Это требует подтверждения надежными термобарометрическими расчетами, включающими Р-Т оценки метаморфизма интенсивно деформированных текто- 
нитов в сравнении с фоновыми значениями ранних этапов эволюции пород. В этой связи, полученные эмпирические данные являются базисом для последующей реконструкции тектоно-термальной эволюции региона и ее интерпретации в рамках известных тектонических моделей.

Исследования проведень в рамках выполнения проектов РФФИ № 18-05-00152 и 18-35-00185.

\section{ЛИТЕРАТУРА}

1. Passchier, C. W. Microtectonics / C. W. Passchier, R. A. J. Trouw // Springer-Verlag, Berlin, Heidelberg, 2nd ed. - 2005. $366 \mathrm{p}$.

2. Thermal interaction of middle and upper crust during gneiss dome formation: example from the Montagne Noire (French Massif Central) / K. Fréville [et al.] // J. Metamorph. Geol. 2016. - V. 34. - P. 447-462.

3. Régnier, J.-L. Metamorphism of Precambrian-Paleozoic schists of the Menderes core series and contact relationschips with Proterozoic orthogneisses of the western cine massif, Anatolide belt, western Turkey / J.-L. Régnier, J. E. Mezger, C. W. Passchier // Geol. Mag. - 2007. - V. 144. - P. 67-104.

4. Природа и модели метаморфизма / В. В. Ревердатто [и др.] - Новосибирск: Изд-во СО РАН. 2017. - 331 с.

5. Tajchmanova, $L$. Pressure variations in metamorphic rocks: Implications for the interpretation of petrographic observations / L. Tajcmanova // Mineralogical Magazine. - 2013. - V. 77 (5). - P. 2300.

6. Multi-stage mountain building vs. relative plate motions in the Betic Cordillera deduced from integrated microstructural and petrological analysis of porphyroblast inclusion trails / D. G. A. M. Aerden [et al.] // Tectonophysics. - 2013. - V. 587. - P. 188-206.

7. Inter-relationships between deformation partitioning, metamorphism and tectonism / T. H. Bell [et al.] // Tectonophysics. 2013. - V. 587. - P. 119-132.

8. Burg, J.-P. The role of viscous heating in Barrovian metamorphism: thermomechanical models and application to the Lepontine Dome in the Central Alps / J.-P. Burg, T. V. Gerya // J. Metamorphic Geol. - 2005. - V. 23. - P. 75-95.

9. Burg, J.-P. Viscous heating allows thrusting to overcome crustal scale buckling: numerical investigation with application to the Himalayan syntaxes / J.-P. Burg, S. M. Schmalholz // Earth Planet. Sci. Let. - 2008. - 274. - P. 189-203.

10. Gerya, T. Tectonic overpressure and underpressure in lithospheric tectonics and metamorphism / T. Gerya // J. Metamorph. Geol. - 2015. - V. 33. - P. 785-800.

11. Schmalholz, S. M. Tectonic overpressure in weak crustalscale shear zones and implications for exhumation of highpressure rocks / S. M. Schmalholz, Y. Y. Podladchikov // Geophysical Researh Letters. - 2013. - V. 40. - P. 1984-1988.

12. Tajchmanova, L. Grain-scale pressure variations in metamorphic rocks: implications for the interpretation of petrographic observations / L. Tajchmanova, J. Vrijmoed, E. Moulas // Lithos. - 2015. - V. 216-217. - P. 338-351.

13. Mancktelow, N. S. Tectonic pressure: Theoretical concepts and models / N. S. Mancktelow // Lithos. - 2008. - V. 103. - P. 149-177.

14. Тен, A. A. Динамическая модель генерации высоких давлений при сдвиговых деформациях горных пород (результаты численного эксперимента) / А. А. Тен // Доклады Академии Наук. - 1993. - Т. 328. - № 3. - С. 322-324.

15. Petrini, $K$. Lithospheric pressure-depth relationship in com- pressive regions of thickened crust / K. Petrini, Yu. Podladchikov // J. Metamorphic Geol. - 2000. - V. 18. - P. 67-77.

16. The problem of depth in geology: When pressure does not translate into depth / E. Moulas [et al.] // Petrology. - 2013. - V. 21(6). - P. 577-587.

17. Schmalholz, S. M. Metamorphism under stress: The problem of relating minerals to depth / S. M. Schmalholz, Y. Y. Podladchikov // Geology. - 2014. - V. 42. - P. 733-734.

18. Ultrafast eclogite formation via melting-induced overpressure / X. Chu [et al.] // Earth Planet. Sci. Lett. - 2017. - V. 479. - P. 1-17.

19. Беляев, О. А. Локальные вариации РТ-параметров тектонометаморфизма в зоне пластического сдвига / О. А. Беляев, Ф. П. Митрофанов, В. П. Петров // Доклады Академии Наук. - 1998. - Т. 361. - № 3. - С. 370-374.

20. Кулаковский, А. Л. Тектонический стресс как дополнительный термодинамический фактор метаморфизма / А. Л. Кулаковский, Ю. А. Морозов, А. И. Смульская // Геофизические исследования. - 2015. - Т. 16. - № 1. - С. 44-68.

21. Коллизионный метаморфизм докембрийских комплексов в заангарской части Енисейского кряжа / И. И. Лиханов [и др.] // Петрология. - 2008. - Т. 16. - № 2. - С. 148-173.

22. Лиханов, И. И. Железисто-глиноземистые метапелиты тейской серии Енисейского кряжа: геохимия, природа протолита и особенности поведения вещества при метаморфизме / И. И. Лиханов, В. В. Ревердатто, А. Е. Вершинин // Геохимия. -2008 . - Т. 46. - № 1. - С. 20-41.

23. Кианит-силлиманитовый метаморфизм докембрийских комплексов Заангарья Енисейского кряжа / И. И. Лиханов [и др.] // Геология и геофизика. - 2009. - Т. 50. - № 12. - С. $1335-1356$.

24. Лиханов, И. И. Коллизионные метаморфические комплексы Енисейского кряжа: особенности эволюции, возрастные рубежи и скорость эксгумации / И. И. Лиханов, В. В. Ревердатто, П.С. Козлов // Геология и Геофизика. 2011. - Т. 52. - № 10. - С. 1593-1611.

25. P-T-t реконструкция метаморфической истории южной части Енисейского кряжа (Сибирский кратон): петрологические следствия и связь с суперконтинентальными циклами / И. И. Лиханов [и др.] // Геология и геофизика. - 2015. - Т. 56. - № 6. - С. 1031-1056.

26. An alternative model for ultra-high pressure in the Svartberget Fe-Ti garnet-peridotite, western gneiss region, Norway / J. C. Vrijmoed [et al.] // Eur. J. Mineral. - 2009. - V. 21. - P. 1119-1133.

27. Pleuger, J. A purely structural restoration of the NFP20-east cross section and potential tectonic overpressure in the Adula nappe (central Alps) / J. Pleuger, Y. Y. Podladchikov // Tectonics. - 2014. - V. 33. - P. 656-685.

28. Геодинамическая эволюция складчатого обрамления и западная граница Сибирского кратона в неопротерозое: геологоструктурные, седиментологические, геохронологические и палеомагнитные данные / В. А. Верниковский [и др.] // Геология и геофизика. - 2009. - Т. 50. - № 4. - С. 380-393.

29. Сальников, А. С. Сейсмологическое строение земной коры платформенных и складчатых областей Сибири по данным региональных сейсмических исследований преломленными волнами / А. С. Сальников - Новосибирск: СНИИГМС, 2009. - $132 \mathrm{c}$.

30. Митрофанов, Г. Л. Структуры скучивания коры некоторых окраинных частей Сибирской платформы / Г. Л. Митрофанов, Т. В. Мордовская, Ф. В. Никольский // Тектоника платформенных областей. - Новосибирск: Наука, 1988. - С. 169-173. 
31. Позднепалеопротерозойские вулканические ассоциации на юго-западе Сибирского кратона (Ангаро-Канский блок) / А. Д. Ножкин [и др.] // Геология и геофизика. - 2016. - Т. 57. - № 2. - С. 312-332.

32. Геохимические и изотопно-геохронологические свидетельства субсинхронного островодужного магматизма и терригенной седиментации (Предивинский террейн Енисейского кряжа) / А. Д. Ножкин [и др.] // Геология и геофизика. - 2016. - Т. 57. - № 11. - С. 1992-2014.

33. Рифейские офиолиты Исаковского пояса (Енисейский кряж) / В. А. Верниковский [и др.] // Геология и геофизика. - 1994. - Т. 35. - № 7-8. - С. 169-181.

34. Возраст бластомилонитов Приенисейской региональной сдвиговой зоны как свидетельство вендских аккреционноколлизионных событий на западной окраине Сибирского кратона / И. И. Лиханов [и др.] // Доклады Академии Наук. - 2013. - Т. 450. - № 2. - С. 199-203.

35. Особенности строения земной коры и верхней мантии юга Сибирской платформы в сечении опорных маршрутов Батолит и Алтай-Северная Земля: Модели земной коры и верхней мантии по результатам глубинного сейсмопрофилирования / В. А. Детков [и др.] // Материалы научнопрактического семинара. - С.-Петербург: ВСЕГЕИ. - 2007. - C. $26-31$.

36. Тектоно-метаморфическая эволюция гаревского полиметаморфического комплекса как свидетельство проявления гренвильских событий на западной окраине Сибирского кратона / П. С. Козлов [и др.] // Геология и геофизика. 2012. - T. 53. - № 11. - C. 1476-1496.

37. Price, N. J. Analysis of Geological Structures / N. J. Price, J. W. Cosgrove // Cambridge University Press. - 1990. - 502 p. 38. Егоров, А. С. Глубинное строение и геодинамика литосферы северной Евразии (по результатам геологогеофизического моделирования вдоль геотраверсов России) / А. С. Егоров // С.-Петербург: ВСЕГЕИ. - 2004. - 199 с.

39. Лиханов, И. И. Минеральные равновесия и Р-Т диаграмма для железисто-глиноземистых метапелитов в системе KFMASH / И. И. Лиханов, В. В. Ревердатто, А. Ю. Селятицкий // Петрология. - 2005. - Т. 13. - № 1. - С. 81-92.

40. Лиханов, И. И. Геохимические свидетельства природы протолита железисто-глиноземистых метапелитов Кузнецкого Алатау и Енисейского кряжа / И. И. Лиханов, В.В. Ревердатто, А.Е. Вершинин // Геология и геофизика. 2006. - T. 47. - № 1. - C. 117-129.

41. Likhanov, I. I. Mass-transfer and differential element mobility in metapelites during multistage metamorphism of Yenisei Ridge, Siberia / I. I. Likhanov // [S. Ferrero, P. Lanari, P. Gonsalves and E. G. Grosch, eds]. Metamorphic Geology: Microscale to Mountain Belts. - London: Geological Society of London, 2018. - Special Publications 478. https://doi.org/10.1144/SP478.11

42. Зональность граната в метапелитах как следствие трех метаморфических событий в докембрийской истории Енисейского кряжа / И. И. Лиханов [и др.] // Петрология. 2013. - Т. 21. - № 6. - С. 612-631.

43. Гренвильские тектонические события и эволюция Енисейского кряжа, западная окраина Сибирского кратона / И. И. Лиханов [и др.] // Геотектоника. - 2014. - Т. 48. - № 5. - C. 32-53.

44. Вендское аккреционно-коллизионное событие на югозападной окраине Сибирского кратона / А. Д. Ножкин [и др.] // Доклады Академии Наук. - 2007. - Т. 415. - № 6. - С. 782-787.

45. Whitney, D. L. Abbreviations for rock-forming minerals / D. L. Whitney, B. W. Evans // American Mineralogist. - 2010. V. 95. - P. 185-187.
46. Первые данные о проявлении мезопротерозойских тектонических событий в геологической истории ЮжноЕнисейского кряжа / И. И. Лиханов [и др.] // Доклады Академии Наук. - 2013. - Т. 453. - № 6. - С. 671-675.

47. Лиханов, И. И. Геохимия, возраст и особенности петрогенезиса пород гаревского метаморфического комплекса Енисейского кряжа / И. И. Лиханов, В. В. Ревердатто // Геохимия. - 2014. - Т. 52. - № 1. - С. 3-25.

48. Качевский, Л. К. Легенда Енисейской серии Государственной геологической карты Российской Федерации масштаба 1:200000 (второе издание) / Ред. Л. К. Качевский // Красноярск: ПГО Красноярскгеология. - 2002. - 200 с.

49. Кузьмичёв, А. Б. Позднерифейский Борисихинский офиолитовый массив (возраст и обстановка формирования) / А. Б. Кузьмичёв, И. П. Падерин, А. В. Антонов // Геология и геофизика. - 2008. - Т. 49. - № 12. - С. 1175-1188.

50. Likhanov, I. I. Blueschist facies fault tectonites from the western margin of the Siberian Craton: Implications for subduction and exhumation associated with early stages of the PaleoAsian Ocean / I. I. Likhanov, J.-L. Régnier, M. Santosh // Lithos. - 2018. - V. 304-307. - P. 468-488.

51. Крылов, А. А. Геохимия, возраст протолита и метаморфизма высокобарических тектонитов Енисейского кряжа: связь с формированием палеоазиатского океана / А. А. Крылов, И. И. Лиханов // Вестн. Воронеж. гос. ун-та. - Сер.: Геология. - 2017. - № 1. - С. 49-60.

52. Лиханов, И. И. Ранние этапы эволюции Палеоазиатского океана на западе Сибирского кратона по данным геохронологических и геохимических исследований Енисейского кряжа / И. И. Лиханов, А. Д. Ножкин, В. В. Ревердатто // Доклады Академии Наук. - 2017. - Т. 476. - № 3. - С. 321326.

53. U-Pb возраст гиперстеновых гранитов (кузеевитов) Ангаро-Канского выступа (Енисейский кряж) / Е. В. Бибикова [и др.] // Геология и геофизика. - 2001. - Т. 42. - № 5. C. $864-867$.

54. Rivers, T. Assembly and preservation of lower, mid, and upper orogenic crust in the Grenville Province - Implications for the evolution of large hot long-duration orogens / T. Rivers // Precambrian Research. - 2008. - V. 167. - P. 237-259.

55. Время формирования и Р-Т параметры метаморфизма метатерригенно-карбонатных отложений Дербинского блока (Восточный Саян) / А. Д. Ножкин [и др.] // Доклады Академии Наук. - 2015. - Т. 461. - № 5. - С. 575-578.

56. Порожнинские гранитоиды Приенисейского офиолитового пояса индикаторы неопротерозойских событий на Енисейском кряже / В. А. Верниковский [и др.] // Доклады Академии Наук. - 2001. - Т. 381. - № 6. - С. 806-810.

57. Лиханов, И. И. Бимодальный внутриплитный магматизм Енисейского кряжа как свидетельство распада Родинии и раскрытия Палеоазиатского океана на западной окраине Сибирского кратона / И. И. Лиханов, В. В. Ревердатто, К. А. Савко // Доклады Академии Наук. - 2017. - Т. 476. - № 6. C. 675-680.

58. Лиханов, И. И. Аккреционная тектоника комплексов западной окраины Сибирского кратона / И. И. Лиханов, А. Д. Ножкин, К. А. Савко // Геотектоника. - 2018. - Т. 52. № 1. - С. 28-51.

59. Лиханов, И. И. Геохимические и геохронологические свидетельства раннего этапа эволюции палеоазиатского океана на западной окраине Сибирского кратона / И. И. Лиханов, С. В. Зиновьев // Геохимия. - 2018. - Т. 56. - № 2. - C. $120-134$.

60. Верниковский, В. А. Тектоника и эволюция гранитоидного магматизма Енисейского кряжа / В. А. Верниковский, 
А. Е. Верниковская // Геология и геофизика. - 2006. - Т. 47. - C. 35-52.

61. Likhanov, I. I. Neoproterozoic intraplate magmatism along the western margin of the Siberian Craton: implications for breakup of the Rodinia supercontinent / I. I. Likhanov, M. Santosh // Precambrian Research. - 2017. - V. 300. - P. 315-331. 62. Fornash, K. F. Tracking the timing of subduction and exhumation using ${ }^{40} \mathrm{Ar} /{ }^{39} \mathrm{Ar}$ phengite ages in blueschist- and eclogite-facies rocks (Sivrihisar, Turkey) / K. F. Fornash, M. A. Cosca, D. L. Whitney // Contribution to Mineralogy and Petrology. - 2016. - V. 171. - №67. doi:10.1007/s00410-016-1268-2. 63. Волкова, Н. И. Высокобарические комплексы Центрально-Азиатского складчатого пояса: геологическая позиция, геохимия и геодинамические следствия / Н. И. Волкова, Е. В. Скляров // Геология и геофизика. - 2007. - Т. 48. -
№ 1. - C. 109-119.

64. Likhanov, I. I. Short-range mobilization of elements in the biotite zone of contact aureole of the Kharlovo gabbro massif (Russia) / I. I. Likhanov, V. V. Reverdatto, I. Memmi // European Journal of Mineralogy. - 1994. - V. 6. - № 1. - P. 133-144. 65. Лиханов, И. И. Минеральные реакции в высокоглиноземистых и железистых роговиках в связи с проблемой устойчивости редких минеральных парагенезисов контактового метаморфизма / Лиханов И. И. // Геология и геофизика. 2003. - T. 44. - № 4. - C. 301-312.

66. Likhanov, I. I. Neoproterozoic collisional metamorphism in overthrust terranes of the Transangarian Yenisey Ridge, Siberia / I. I. Likhanov, V. V. Reverdatto // International Geology Review. - 2011. - V. 53. - № 7. - P. 802-845.

Sobolev Institute of Geology and Mineralogy of Siberian Branch, Russian Academy of Sciences, Novosibirsk СО РАН, Новосибирск

Лиханов Игорь Иванович, доктор геолого-минералогических наук, профессор, ведущий научный сотрудник E-mail:likh@igm.nsc.ru Тел.: 8 (383) 333-02-39

Крылов Александр Александрович, младиий научный сотрудник

E-mail: krylov@igm.nsc.ru

Тел.: 8 (383) 333-02-39

Университет Мугла, Мугла, Туриия

Ренье Жан-Люк, доктор философии, профессор E-mail: jean_lucregnier@mu.edu.tr
Likhanov I. I., Doctor of Geological and Mineralogical Sciences, Professor, Principal Research Fellow

E-mail: likh@igm.nsc.ru

Tel.: 8 (383) 333-02-39

Krylov A. A., Junior Researcher

E-mail: krylov@igm.nsc.ru

Tel.: 8 (383) 333-02-39

Department of Geological Engineering, Muğla University, Muğla, Turkey

Régnier Jean-Luc, PhD, Professor

E-mail: jean_lucregnier@mu.edu.tr 